\title{
O PEWNYCH WSPÓLNYCH CECHACH IX-WIECZNEJ CERAMIKI Z OBSZARU PÓŁNOCNEJ I POLUDNIOWEJ CZĘ́SCI OBECNEGO DOLNEGO ŚLĄSKA
}

\author{
COMMON FEATURES SHARED BY $9^{\mathrm{TH}}$ CENTURY CERAMICS \\ FROM THE NORTH AND THE SOUTH OF LOWER SILESIA
}

\begin{abstract}
This article presents the results of comparative research into $9^{\text {th }}$ century vessels discovered in numerous archaeological sites in Lower Silesia. The research was underpinned with petrographic analyses of ceramics representing a progressive trend in pottery. The reason why this issue is discussed is the occurrence of vessels with similar technological and stylistic attributes in both the south and the north of the region under scrutiny. The research leads to a conclusion that the common features shared by the ceramics artefacts may result from foreign influences in the north and the south of the region alike. However, numerous similarities in the final touches of the vessels indicate that in the first half of the $9^{\text {th }}$ century (if not later), Silesian potters shared their experiences while the populations of the north and the south of the region and exchanged various artefacts including vessels. This exchange of experience in pottery production bore fruit in the form of stylistically and formally diverse vessels.
\end{abstract}

Keywords: Early Middle Ages, $9^{\text {th }}$ century, a comparative analysis of ceramics, smooth ceramics, Lower Silesia, petrographic tests.

Prowadzone w ostatnich latach zintensyfikowane studia nad wczesnośredniowieczną ceramiką pochodzącą z licznych stanowisk położonych na obecnym pograniczu dolnośląsko-łużycko-wielkopolskim (Gruszka 2012, 2013, 2014, 2015, 2016a; Gunia i Gruszka 2010, 2011; Gunia 2012a, 2012b, 2013a, 2013b, 2014a, 2014b, 2016a, 2016b; Pawlak i Pawlak 2013; Pawlak 2012, 2013; Kobylińska 2014; Dębski 2014) oraz w południowej części Dolnego Śląska (Pankiewicz 2012) oprócz tego, że przyczyniły się do lepszego poznania ówczesnego „warsztatu garncarskiego", to dały także asumpt do rozważań na temat relacji kulturowych tych

* Ośrodek Studiów Pradziejowych i Średniowiecznych, Instytut Archeologii i Etnologii PAN, ul. Rubież 46, 61-612 Poznań, e-mail: bartekgruszka@poczta.onet.pl.

** Instytut Archeologii, Uniwersytet Wrocławski, ul. Szewska 48, 50-139 Wrocław, e-mail: ohlap@ poczta.onet.pl. 


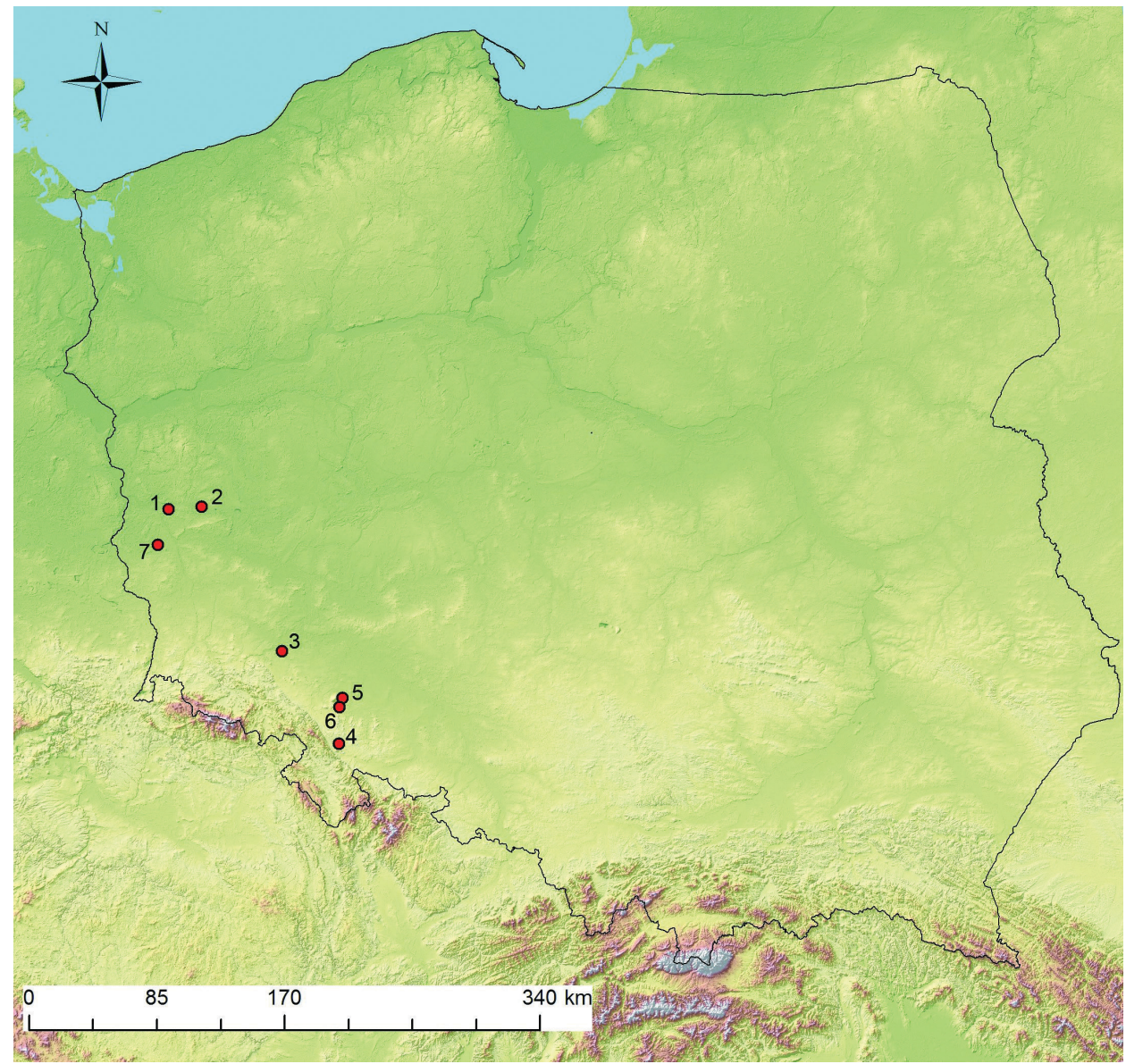

Ryc. 1. Lokalizacja głównych stanowisk, z których pochodzą fragmenty naczyń omawiane w artykule:

1 - Połupin, stan. 2; 2 - Sulechów, stan. 28; 3 - Mierczyce; 4 - Gilów; 5 - Stary Zamek; 6 - Będkowice; 7 - Nowiniec, stan. 2 (oprac. B. Gruszka, A. Łuczak)

obszarów z terenami ościennymi, głównie położonymi na zachód i południe (Pankiewicz 2012; Pawlak 2013, s. 249-251; Gruszka i Kara 2013; Gruszka 2016a, s. 180-186). Szczegółowe studia nad ceramiką są bowiem niezbędnym wstępem do dalszych badań dotyczących m.in. kontaktów interregionalnych (por. Bojarski 2012, s. 10-11, 228-251; Pankiewicz 2012, s. 16-17).

Celem artykułu jest przedstawienie nie tylko podobieństw stylistycznych, formalnych, ale także technologicznych naczyń odkrytych na wybranych stanowiskach z obszaru Dolnego Śląska (ryc. 1) w jego północnej i południowej partii. Omawiane zagadnienia zostały wsparte wynikami analiz petrograficznych ceramiki charakteryzującej się cechami progresywnego nurtu garncarstwa z IX wieku. 
Przyczynkiem do podjęcia zagadnienia jest występowanie zarówno w południowych, jak i w północnych obszarach obecnego Dolnego Śląska zespołów naczyń datowanych ogólnie na IX w., które odznaczają się zestawem zbieżnych cech technologicznych i stylistycznych. W przypadku obszaru położonego na północy chodzi o występowanie naczyń, do których produkcji stosowano odpowiednio przygotowane masy garncarskie, oparte m.in. na selekcjonowanej, drobnoziarnistej (pelityczno-aulerytowej) domieszce schudzającej, wśród której spotykane są m.in. minerały ciemne $\mathrm{z}$ grupy amfiboli (np. hornblenda zwyczajna) czy pirokseny. W przypadku stylistyki naczynia te charakteryzują się brakiem zdobienia, odpowiednim opracowaniem powierzchni zewnętrznej (tzw. ceramika gładka, o silnie wygładzanych ściankach, czasami do połysku), z dodatkowo silnym profilowaniem i niekiedy znacznym pogrubieniem wylewów. Naczynia te były obtaczane, jednak wykorzystanie rotacji koła garncarskiego nie ograniczało się jedynie do zlepiania kolejnych poziomów porcji masy garncarskiej, lecz także służyło do nadawania naczyniom ostatecznego kształtu, faktury oraz do silnej profilacji zwieńczeń.

Naczynia charakteryzujące się takimi cechami wystąpiły w północnej partii Dolnego Śląska m.in. na osadzie w Sulechowie, stan. 28, datowanej ogólnie na IX w. (Gruszka 2013, s. 412, ryc. 2-4) oraz na grodzisku w Połupinie, stan. 2 (ryc. 5-8), które na podstawie nowych ustaleń można datować na okres od 3. ćwierci VIII do połowy IX wieku (Gruszka 2016b, s. 243).

$\mathrm{Na}$ obu stanowiskach naczynia o takich cechach występowały wraz z nieornamentowanymi garnkami wykonanymi $\mathrm{w}$ miejscowej tradycji, które charakteryzowały się mniej lub bardziej esowatymi profilami i różnorodnymi formami - od przysadzistych po bardziej smukłe (Gruszka 2013, ryc. 53:3; 58:1, 2; 59:1; 61:8, $11 ; 63: 4,6 ; 67: 2,4 ; 69: 5,70: 1 ; 73: 8 ; 74: 15 ; 75: 2 ; 2016 a$, np. ryc. 29:5; 31:2; 33:1; $34: 2,3 ; 35 ; 36: 2-4 ; 38 ; 39: 1,2,4,6 ; 41: 4 ; 46 ; 47: 1,13,14 ; 53: 1 ; 57 ; 59 ; 61: 1$; 63:2), jednak udział naczyń o cechach progresywnych jest na tyle duży, że wyraźnie zaznacza się $\mathrm{w}$ analizowanych materiałach. Jedną z cech wspólnych tej zaawansowanej technologicznie grupy naczyń jest częste stosowanie mineralnych domieszek schudzających, złożonych głównie z tłucznia granitowego, plagioklazów i skaleni, niekiedy intencjonalnie przygotowanych i odsianych do pożądanej frakcji (Gunia 2016a, s. 295-306). Na podstawie badań petrograficznych stwierdzono także, że wśród naczyń o gładkich ściankach występują egzemplarze wykonane z masy garncarskiej zawierającej, jako składniki nieplastyczne, niewielkie ilości słupków ciemnozielonych amfiboli czy pirokseny. Są to minerały charakterystyczne dla przedpola Gór Sowich, Masywu Ślęży i dorzecza Ślęzy aż po Wrocław (Stoksik 2007, s. 102; Łydżba-Kopczyńska i in. 2008, tab. 2; August 2008, s. 3; Pankiewicz 2012, s. 238; por. też Gunia 2012a, s. 324-325). Warto dodać, że w późniejszym okresie, w drugiej połowie IX i w X w., amfibole, jako jeden ze składników nieplastycznych masy garncarskiej, pojawia się niezwykle rzadko, np. wśród ceramiki o południowych nawiązaniach w Nowińcu, stan. 2 (Gunia 2012a, s. 324-325; Gruszka 2012, s. 81), lecz są także przypadki, gdzie nie odnotowano tego rodzaju 

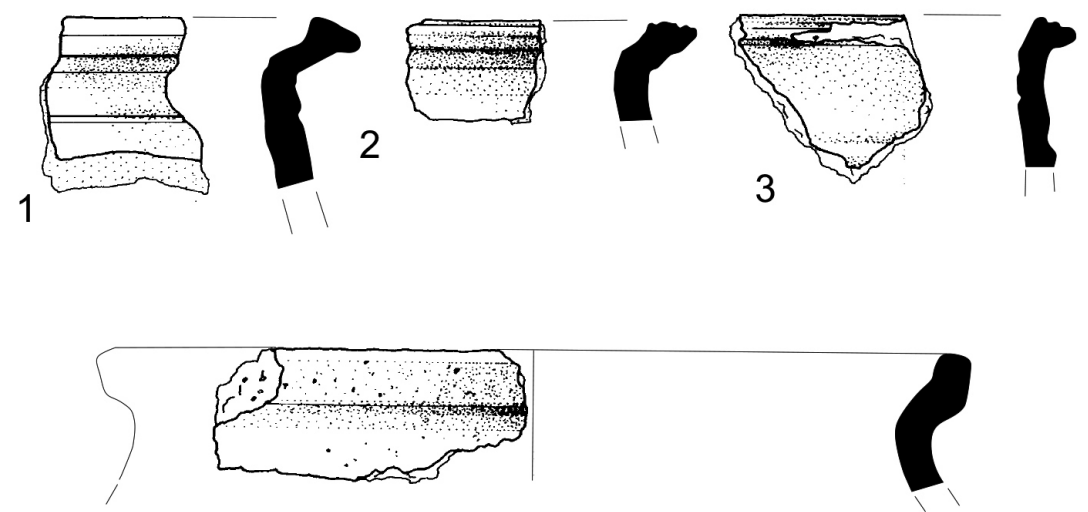

4

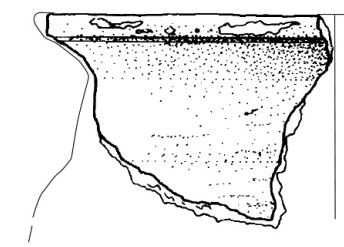

5
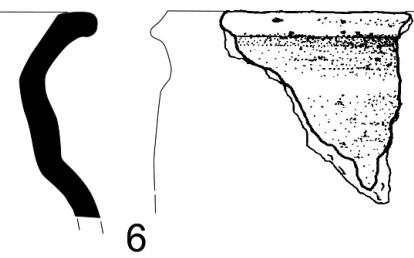

6
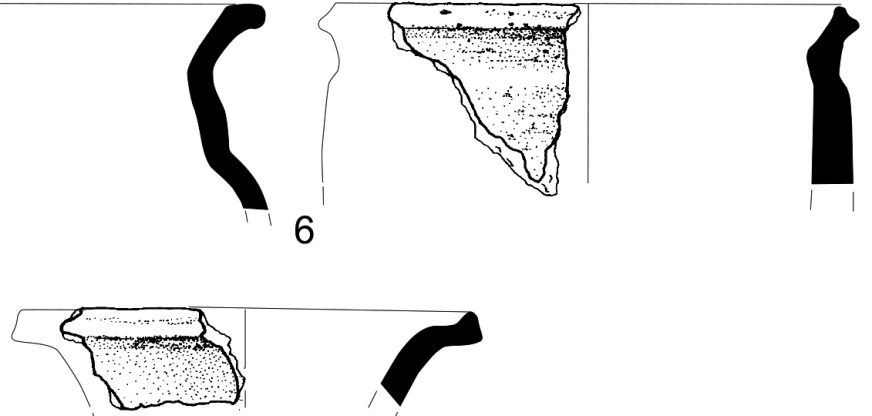

7

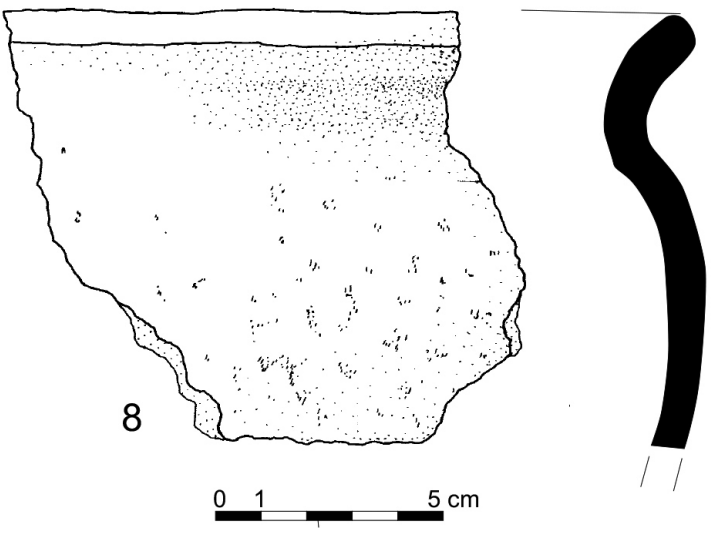

Ryc. 2. Sulechów, stan. 28, woj. lubuskie. Przykłady naczyń nieornamentowanych o gładkich ściankach i silnie profilowanych wylewach:

1-3 - obiekt 1; 4-8 - obiekt 22 (rys. D. Krzyżyńska) 

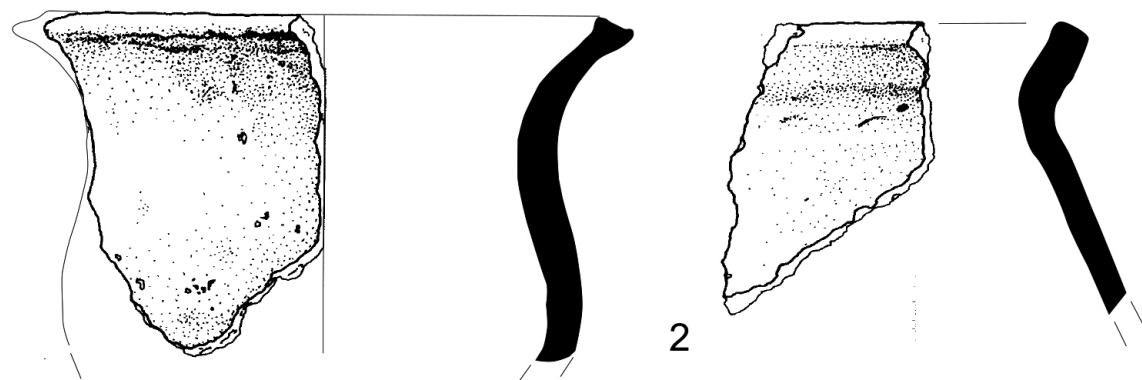

1
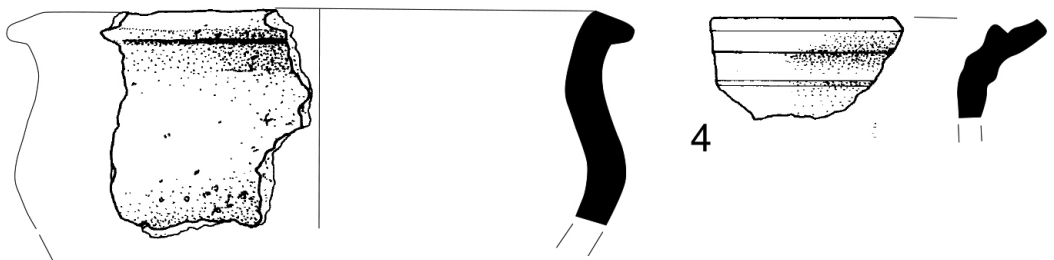

3
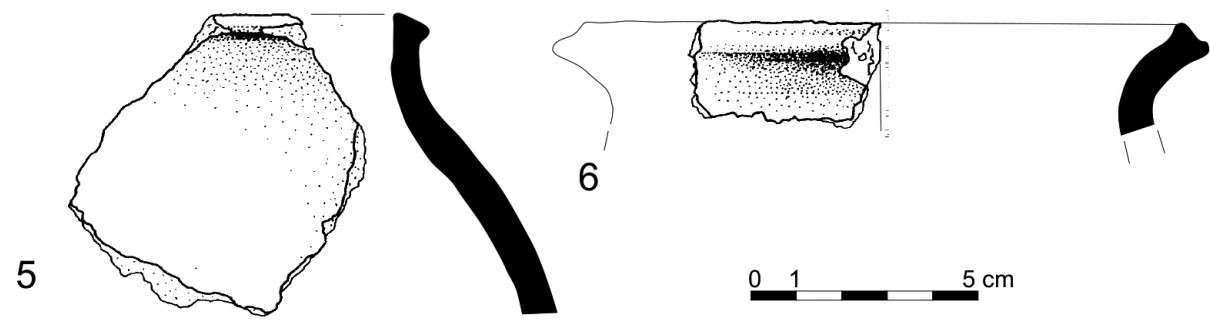

6
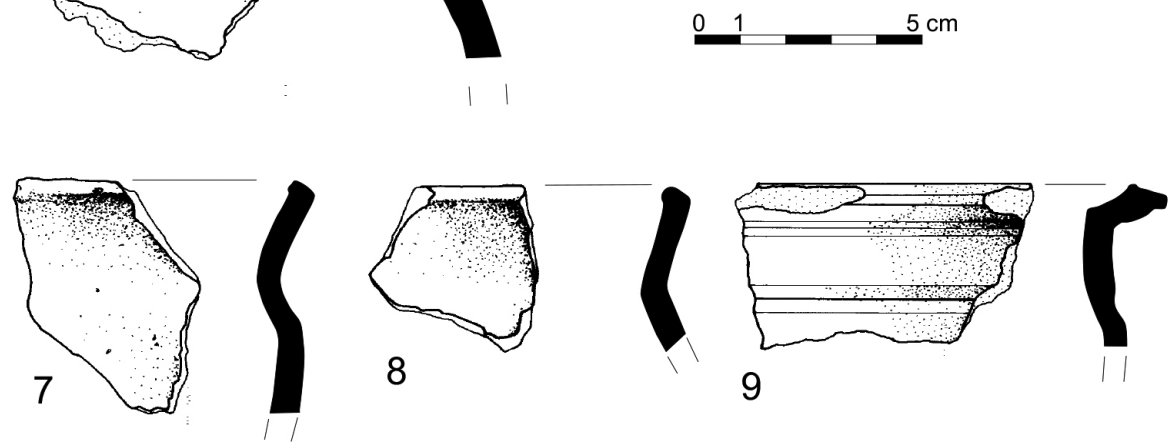

Ryc. 3. Sulechów, stan. 28, woj. lubuskie. Przykłady naczyń nieornamentowanych o gładkich ściankach i silnie profilowanych wylewach: 1-4 - obiekt 23; 5 - obiekt 30;6 - 49; 7-9 - obiekt 80 (rys. D. Krzyżyńska) 

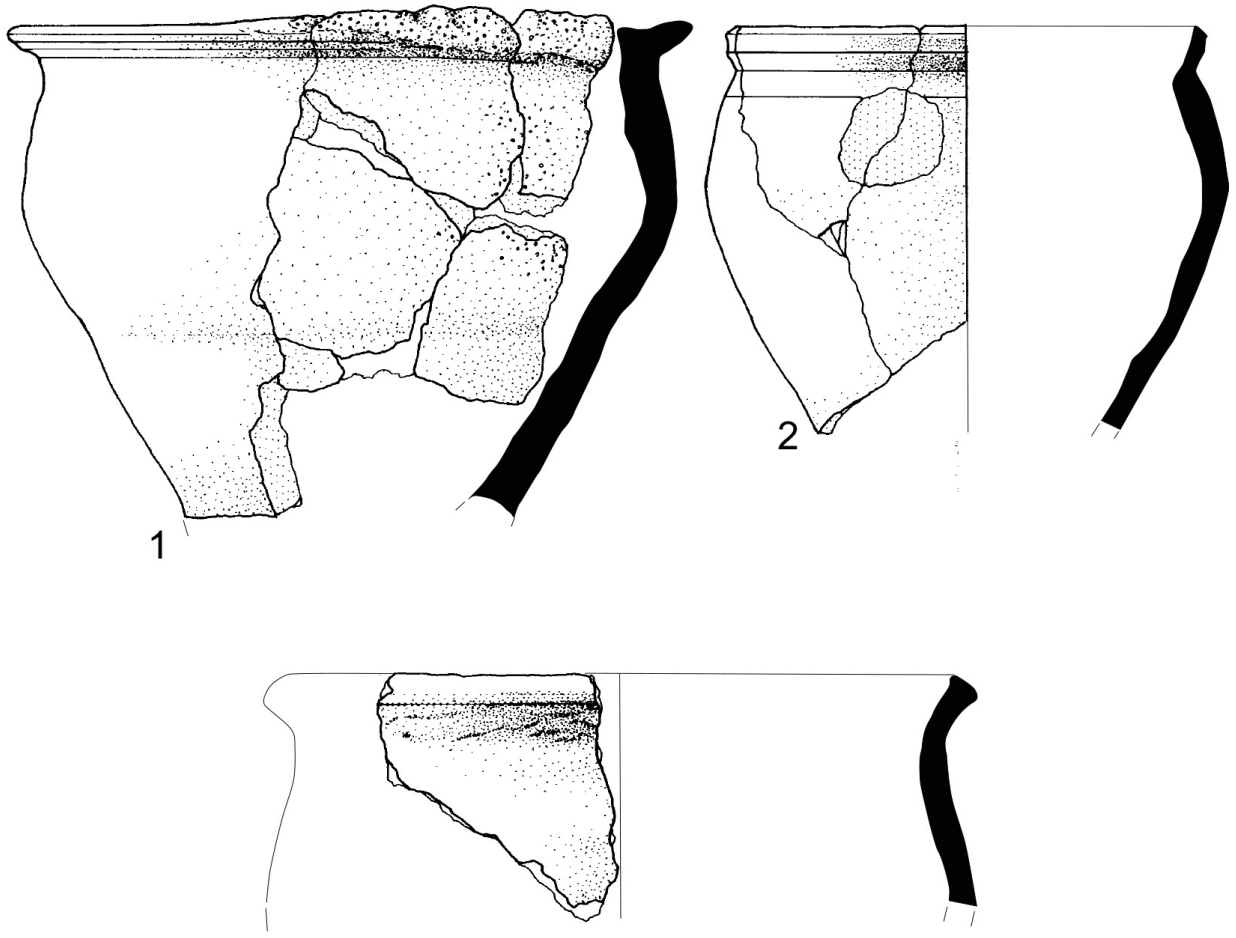

3

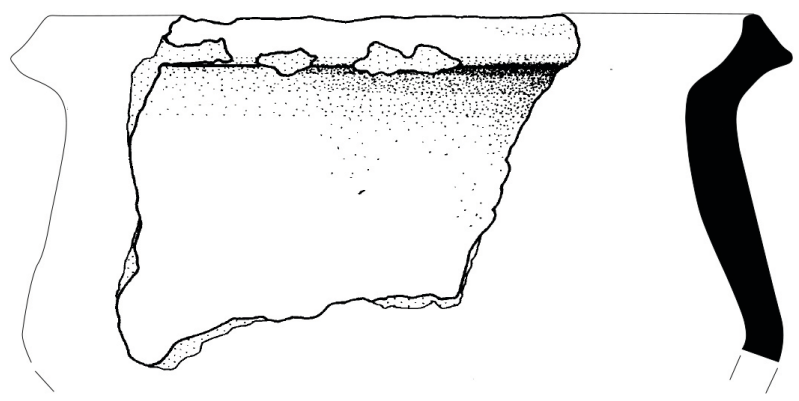

4

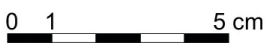

Ryc. 4. Sulechów, stan. 28, woj. lubuskie. Przykłady naczyń nieornamentowanych o gładkich ściankach i silnie profilowanych wylewach odkrytych w obiekcie 40 (rys. D. Krzyżyńska) 

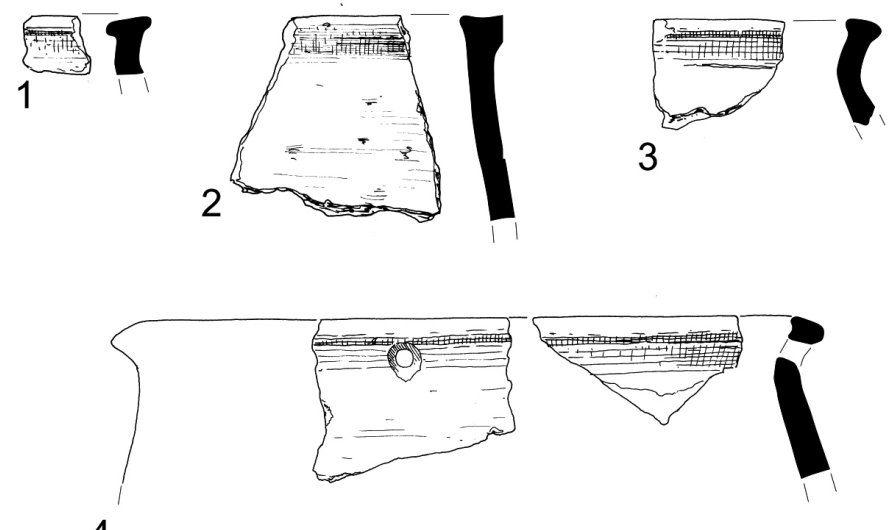

4

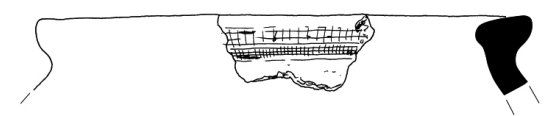

5

6
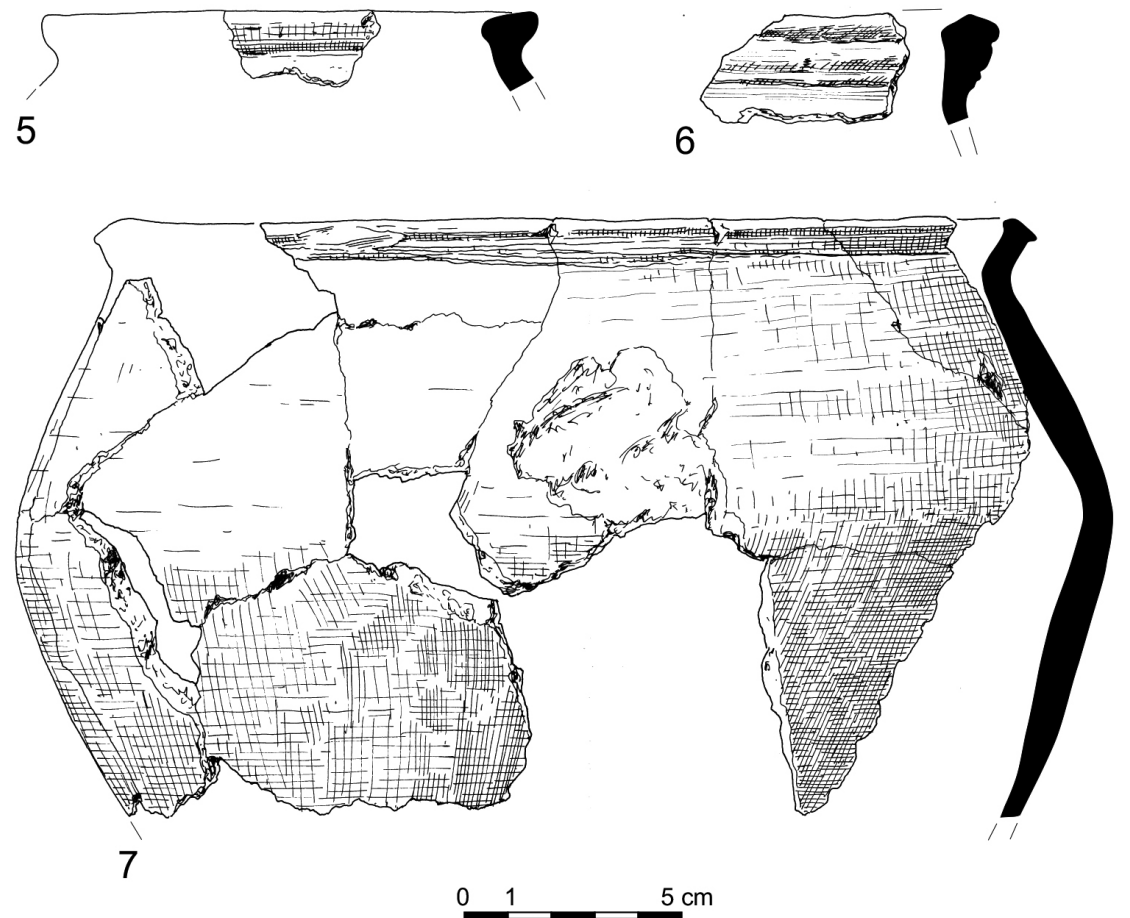

Ryc. 5. Połupin, stan. 2, woj. lubuskie. Przykłady naczyń nieornamentowanych o gładkich ściankach i silnie profilowanych wylewach:

1 - warstwa humusu, wykop 1 (nr inw. 33/61); 2 - warstwa humusu, wykop 6 (nr inw. 55/61); 3 - znalezisko luźne; 4 - z doczyszczania profilu zachodniego w wykopie 1 ( $\mathrm{nr}$ inw. 50/61); 5, 7 - z poziomu kamieni i spomiędzy kamieni w wykopie 1 (warstwa B; nr inw. 10/61); 6 - z poszerzenia fosy w wykopie 4 , z poziomu spomiędzy dużych kamieni (nr inw. 77/61) (rys. E. Dąbrowski, E. Pawlak) 

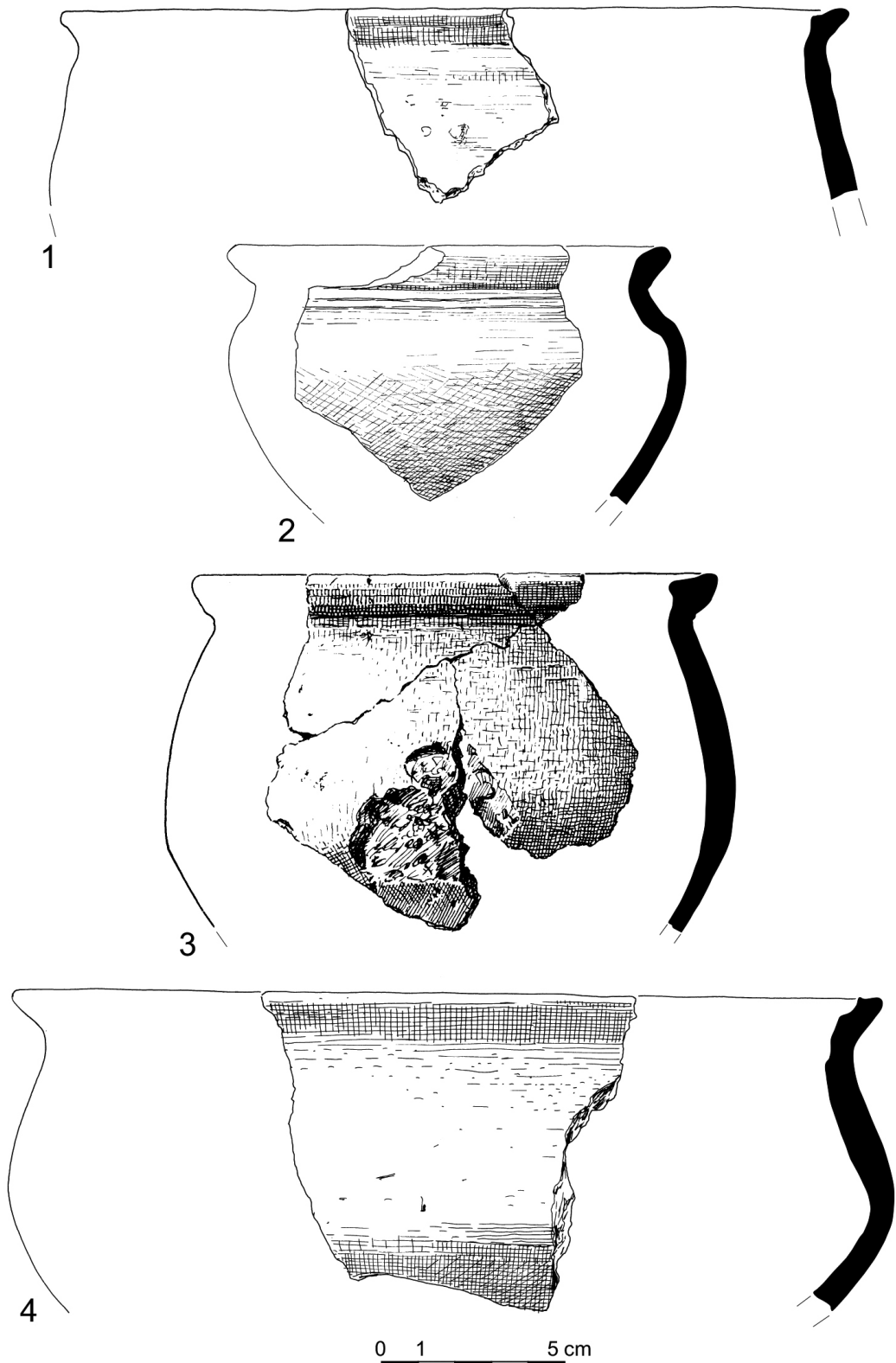

Ryc. 6. Połupin, stan. 2, woj. lubuskie. Przykłady naczyń nieornamentowanych o gładkich ściankach i silnie profilowanych wylewach:

1-3 - z „fosy” nr 2 w zachodniej części wykopu 4, z poziomu spomiędzy kamieni (nr inw. 80/61); 4 - spomiędzy kamieni rozsypiska wału w wykopie 6 (nr inw. 49/61) (rys. E. Dąbrowski, E. Pawlak) 
minerałów w ogóle, jak to było np. w analizowanych fragmentach naczyń z osady w Zawadzie, stan. 1 (Gunia 2014a).

Kolejną charakterystyczną cechą omawianych naczyń jest brak zdobienia oraz silne wygładzanie powierzchni naczyń, czasami do połysku. Zabiegi wygładzania i obmazywania naczyń powodowały zatarcie, w większości analizowanych przykładów, śladów lepienia, powodując jednocześnie, że powierzchnie garnków stawały się bardziej równe, choć odznaczały się różną fakturą. W przypadku Połupina, wśród 336 naczyń, które przeanalizowano pod kątem opracowania powierzchni, dominowały naczynia o obu ściankach równych, nieznacznie szorstkich $(47,9 \%)$. Duży jest jednak odsetek naczyń o ściankach gładkich, niekiedy silnie wyświecanych. W przypadku powierzchni zewnętrznych taką fakturę stwierdzono w 30,7\% badanych egzemplarzy. Obie gładkie powierzchnie odnotowano w 11,3\% wszystkich analizowanych naczyń (Gruszka 2016a, s. 146). W porównaniu do naczyń z innych stanowisk położonych na północnych peryferiach dzisiejszego Dolnego Śląska udział ceramiki „gładkiej” w Połupinie jest wyjątkowo wysoki. Dla przykładu można podać, że na osadzie w Sulechowie, stan. 28, która funkcjonowała w zbliżonym okresie co gród w Połupinie, odsetek naczyń o gładkich ściankach wynosił 7,5\% (Gruszka 2013, s. 393). Podobny udział naczyń „gładkich" (ok. 8\%) odnotowano na osadzie z końca VII i początku VIII w. w Mozowie, stan. 23 koło Sulechowa (Gruszka 2015, s. 90, tab. 3). Z kolei na stanowiskach młodszych, datowanych od około połowy IX w., udział ceramiki ,gładkiej” był znikomy. Na przykład na osadzie w Klenicy, stan. 4, wynosił on niecałe 4\% (Gruszka 2010, tab. 6, s. 121), podobnie było w przypadku naczyń z osady w Zawadzie, stan. 1 (Gruszka 2012, s. 109-110).

Warto także odnotować, że większość naczyń o gładkich ściankach, które zostały poddane analizom petrograficznym, była angobowana, jedno- lub obustronnie, rzadką, szlamowaną glinką. Jako przykłady można podać dwa naczynia pochodzące ze stan. 28 w Sulechowie (próbka p.c. 9 i p.c. 22), na których w peryferycznych partiach powierzchni zewnętrznej stwierdzono cienkie warstewki gliny pozbawionej domieszki nieplastycznej (p.c. 22; ryc. 4:2) lub zawierającej pył kwarcowy (p.c. 9) (Gunia 2013a, s. 471, 479; Gruszka 2013, s. 410-411).

O pewnych progresywnych cechach naczyń obcych tradycyjnemu, lokalnemu garncarstwu świadczą także wylewy profilowane za pomocą silnej rotacji koła garncarskiego (np. ryc. 2:1-3, 6; 3:4, 5, 9; 5; 6:3; 7:3; 8), które można przyporządkować następującym typom wydzielonym m.in. dla ceramiki z Połupina: F3 (Gruszka 2016a, z typu F3, np. ryc. 30:11; 13, 42:6, 12; 56:3; z typu F4, np. ryc. $30: 31 ; 41: 6 ; 50: 7 ; 52: 2$; z typu F6, np. ryc. 37:4; 45:5; z typu G4, np. ryc. $33: 2 ; 34: 1 ; 35: 8 ; 36: 3 ; 39: 8 ; 47: 5 ; 48: 3 ; 54: 10 ; 58: 11$; z typu H5, np. ryc. $32: 11 ; 40: 39 ; 55: 4 ; 62: 5 ; 67: 1,3 ; 75: 9 ;$ z typu J1, np. ryc. 36:5; 45:1; 47:7; 64:4; z typu J4, np. ryc. 50:6 i z typu specjalnego ryc. 40:32; 44:9; 50:16). Część wymienionych powyżej krawędzi naczyń z Połupina znajduje ścisłe odpowiedniki wśród materiałów odkrytych na osadzie z IX w. w Sulechowie, stan. 28. Dotyczy 

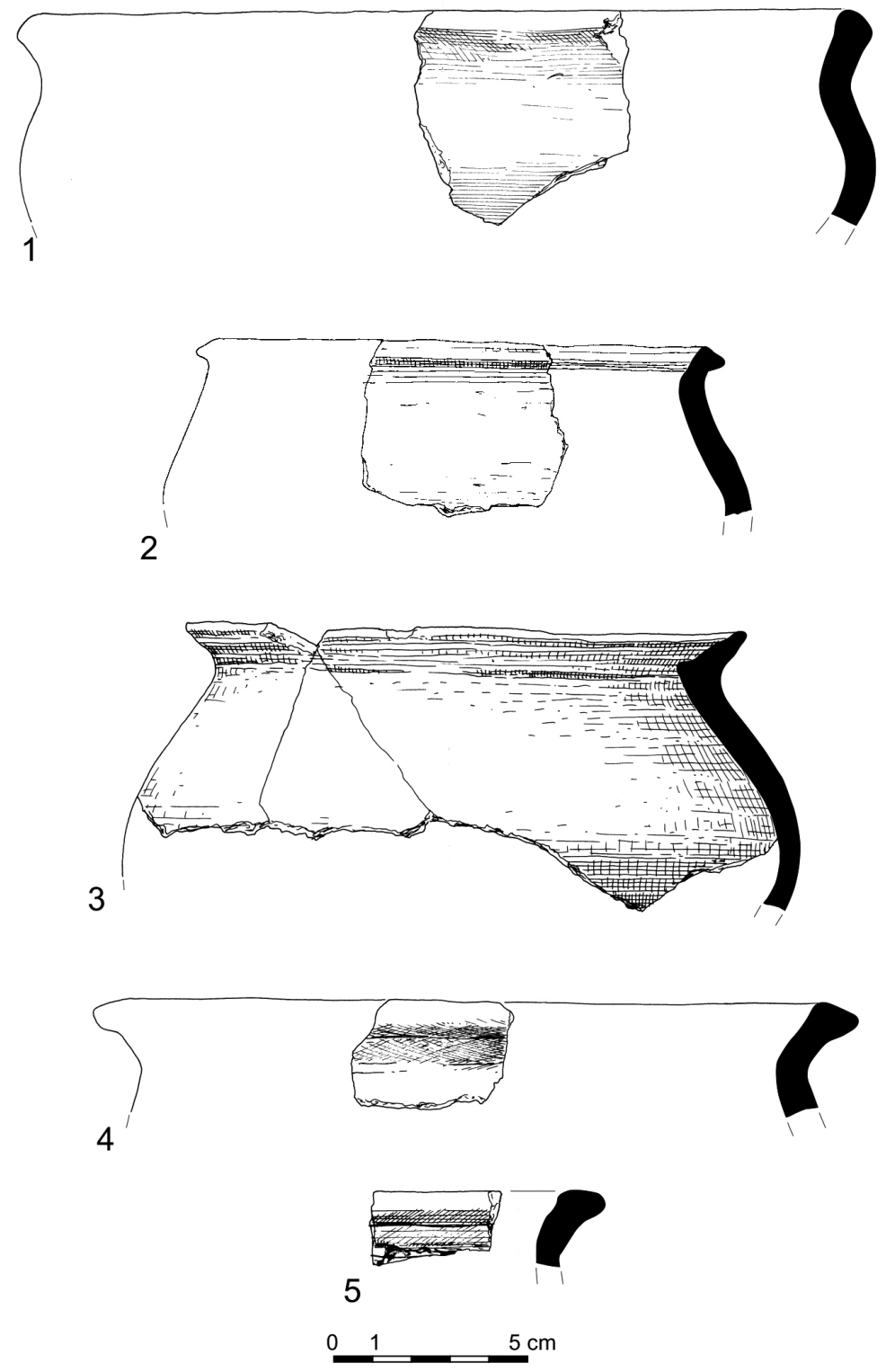

Ryc. 7. Połupin, stan. 2, woj. lubuskie. Przykłady naczyń nieornamentowanych o gładkich ściankach i silnie profilowanych wylewach:

1 - z warstwy spalenizny z dużą ilością węgli drzewnych w wykopie 6 (od 7 do $10 \mathrm{~m}^{2}$ ) (nr inw. 83/61); 2 - jama 2, wykop 6 (nr inw. 114/61); 3 - znalezisko luźne (nr inw. 130/61); 4, 5 - z warstwy powyżej kamieni i spomiędzy kamieni będących rozsypiskiem lica wewnętrznego wału (wykop 6 i 7; nr inw. 2/63) (rys. E. Dąbrowski, E. Pawlak) 

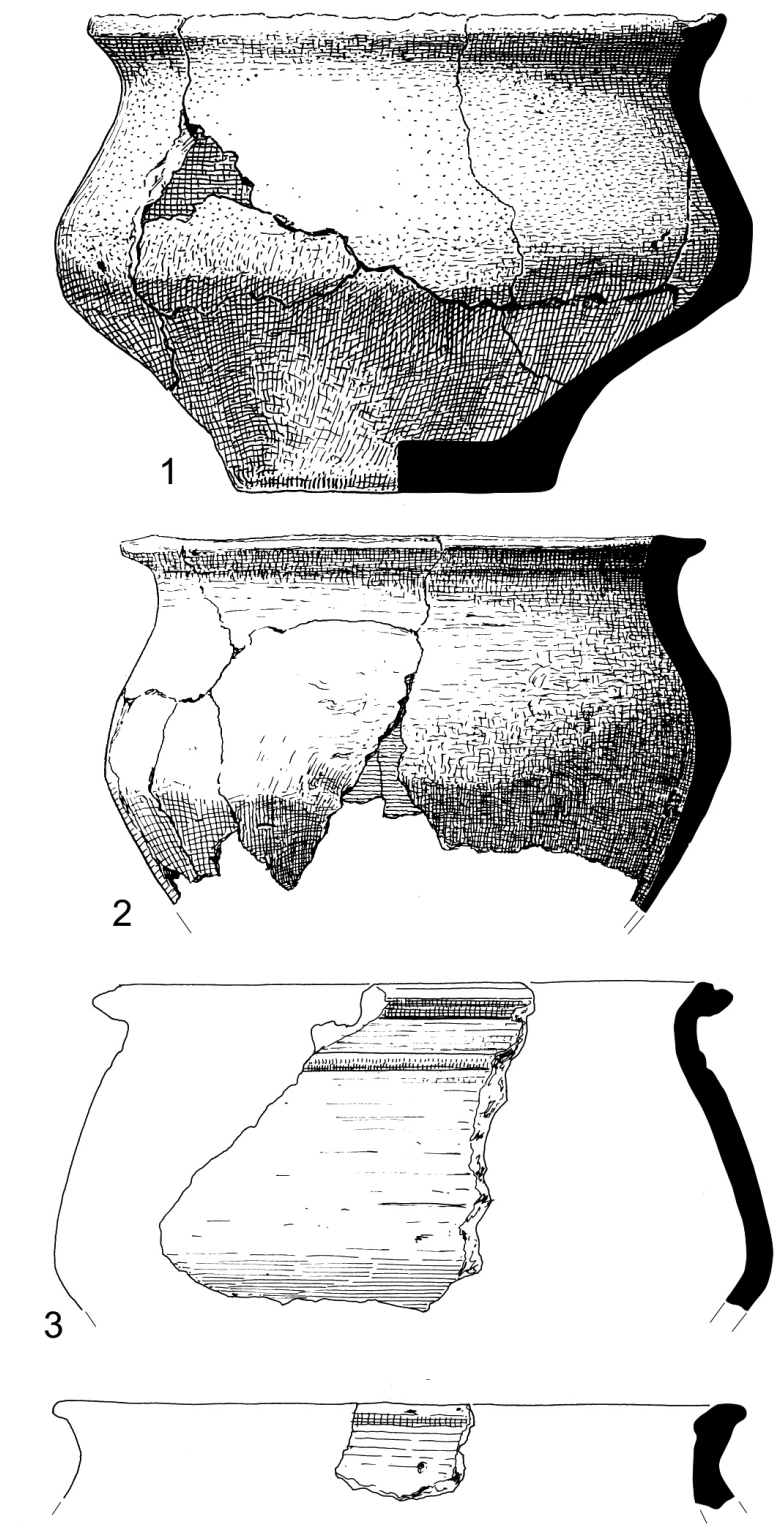

4

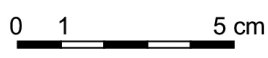

Ryc. 8. Połupin, stan. 2, woj. lubuskie. Przykłady naczyń nieornamentowanych o gładkich ściankach i silnie profilowanych wylewach:

1-2 - z warstwy powyżej kamieni i spomiędzy kamieni będących rozsypiskiem lica wewnętrznego wału (wykop 6 i 7; nr inw. 2/63); 3 - palenisko odkryte pod kamieniami obsuniętymi z konstrukcji wału (nr inw. 24/63); 4 - warstwa pod paleniskiem (nr inw. 16/63) (rys. E. Dąbrowski, E. Pawlak) 

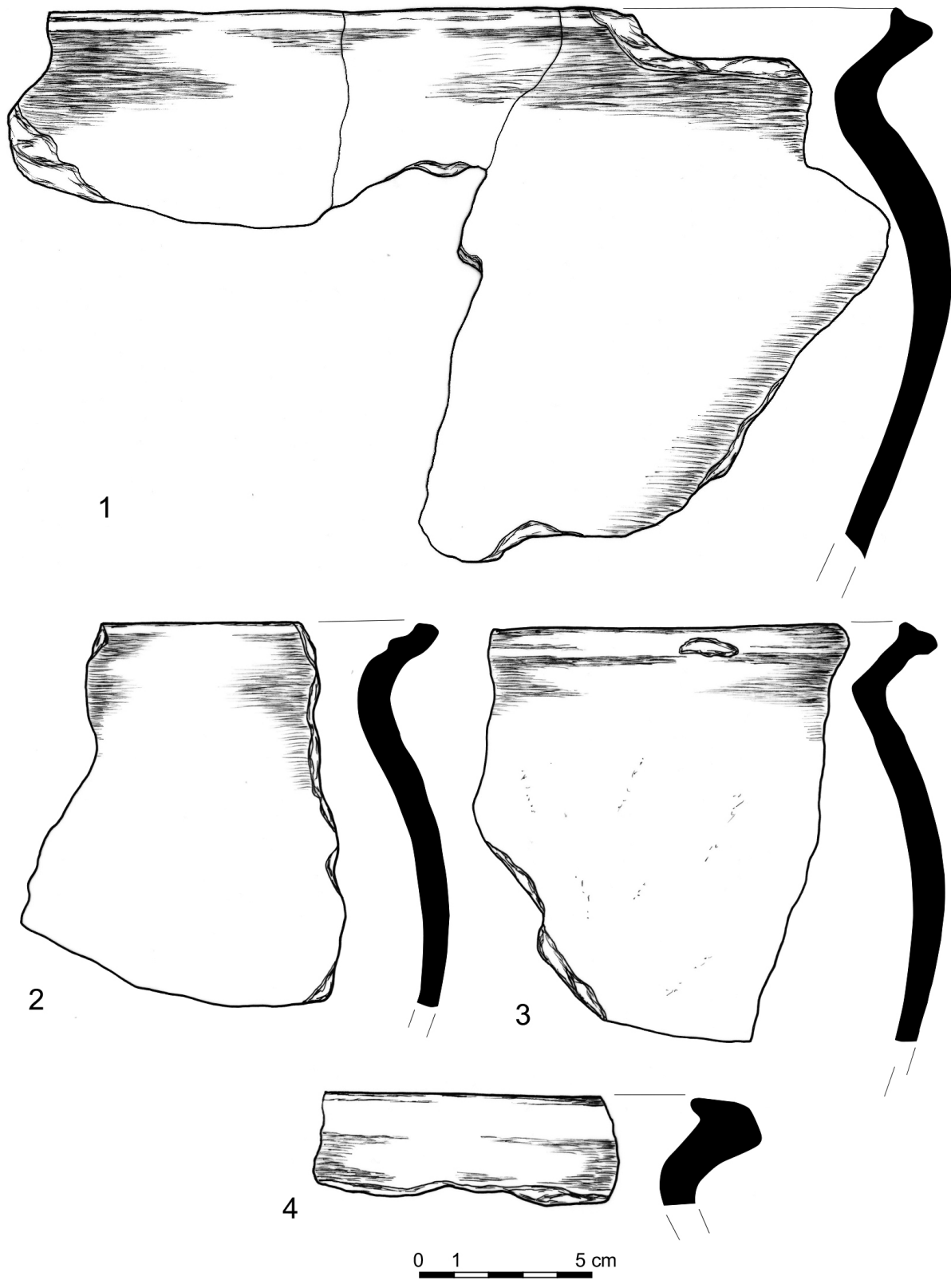

Ryc. 9. Mierczyce, woj. dolnośląskie. Przykłady naczyń nieornamentowanych o gładkich ściankach i silnie profilowanych wylewach (rys. A. Pankiewicz) 
to zwłaszcza naczyń zwieńczonych wylewami typu F4 (Gruszka 2013, ryc. 73:2), G4 (Gruszka 2013, ryc. 53:4, 7; 65:2, 3; 67:1, 4; 71:3), H5 (Gruszka 2013, ryc. 57:9; 61:3, 6, 10; 63:2; 64:5), J1 (Gruszka 2013, ryc. 69:1), J4 (Gruszka 2013, ryc. 69:2) oraz typu specjalnego (Gruszka 2013, ryc. 53:5; 60:2, 3). Niektóre $\mathrm{z}$ tych krawędzi mają ścisłe odpowiedniki wśród znalezisk ze stanowisk w Mierczycach (ryc. 9; 10), Będkowicach (ryc. 11) czy Starym Zamku (ryc. 12). Zarówno na północy, jak i na południu omawianego obszaru szczególną uwagę zwracają bardzo masywne, profilowane od strony zewnętrznej, wewnętrznej i górnej, krawędzie przypominające szeroką kryzę (np. ryc. 5:5, 6; 6:3; 9:1, 4; 10:6). Tego typu formy brzegów nie były wcześniej znane w środowisku miejscowym, zarówno na północy, jak i południu omawianego terenu, dlatego przypuszczamy, że ich pojawienie się można łączyć z wpływami obcego warsztatu garncarskiego. W przypadku silniej profilowanych okazów z północnych terenów Dolnego Śląska, zdobionych dodatkowo dookolnymi listwami plastycznymi, jako przypuszczalne źródło inspiracji ich produkcji wskazano wyroby pochodzące z obszaru merowińskiego kręgu kulturowego oraz ziem dorzecza dolnego Dunaju, zwłaszcza formy typu Knickwandtopf (Gruszka i Kara 2013; Pawlak 2013, s. 250-251). Analogii tej nie możemy jednak odnieść do odmiennych stylistycznie naczyń z południa Dolnego Śląska. Być może nośnikiem wzorców dla garncarzy wytwarzających naczynia na tym obszarze były właśnie wyroby z pogranicza śląsko-wielkopolsko-łużyckiego lub podobieństwa te są wynikiem nierozpoznanych jeszcze wpływów zewnętrznych.

Naczynia z Mierczyc, Starego Zamku i Będkowic w zdecydowanej większości należą do form A1 A2, ewentualnie B (wg Pankiewicz 2012, s. 40-42, 47-48, ryc. 4 ; 5; 9) z krótką esowatą szyjką i łukowatym, z zasady dość wysoko załamanym, brzuścem (A1, A2) lub szyjką zredukowaną (B). W Mierczycach liczniej wystąpiły jednak także naczynia o ostrym załomie brzuśca i silniej podciętym dnie. Są one typowe dla północnych terenów Dolnego Śląska (typy C3, C4 naczyń z Klenicy - Gruszka 2010, s. 127-129, ryc. 10-11, Nowińca - Gruszka 2012, s. 61-65, ryc. 8-10, Sulechowa - Gruszka 2013, s. 401, ryc. 41, tab. 8, Zawady Gruszka 2014, s. 89, ryc. 8-9 i z Połupina - Gruszka 2016, s. 166-172, ryc. 18-20; Rzeźnik 1997, s. 276, ryc. 4:a, 6:a; Biermann i in. 2011, ryc. 21:6), natomiast na południu są one spotykane tylko sporadycznie i poza wzmiankowanymi okazami z Mierczyc ich obecność stwierdzono jeszcze w Legnicy (Pankiewicz 2012, tabl. 71:h; 73:b, g, h; 74:c). W ceramice mierczyckiej zwraca uwagę także wysoka, jak na środowisko lokalne, frekwencja wątków grzebykowych w układach pionowych (Pankiewicz 2012, tabl. 82:d, 83:b), relatywnie rzadko spotykanych na południu (por. Pankiewicz 2012, s. 62-63, 87, ryc. 28), a stosowanych powszechnie na północy regionu (Pokora, Rzeźnik 1998, s. 330-331, ryc. 4:b-d; Siemianowska 2010, s. 211, ryc. 5; Biermann i in. 2011, ryc. 21:8, 9; 22:2; typy ornamentów II:VIII i II:IX z Klenicy - Gruszka 2010, s. 125, 131-132, ryc. 7; Kieseler 2016, ryc. 6:2; 7:2, 5; 24:8; 44:3; 48:3, 4; Nowińca - Gruszka 2012, s. 52, 56, ryc. 2, tab. 1, 2; 

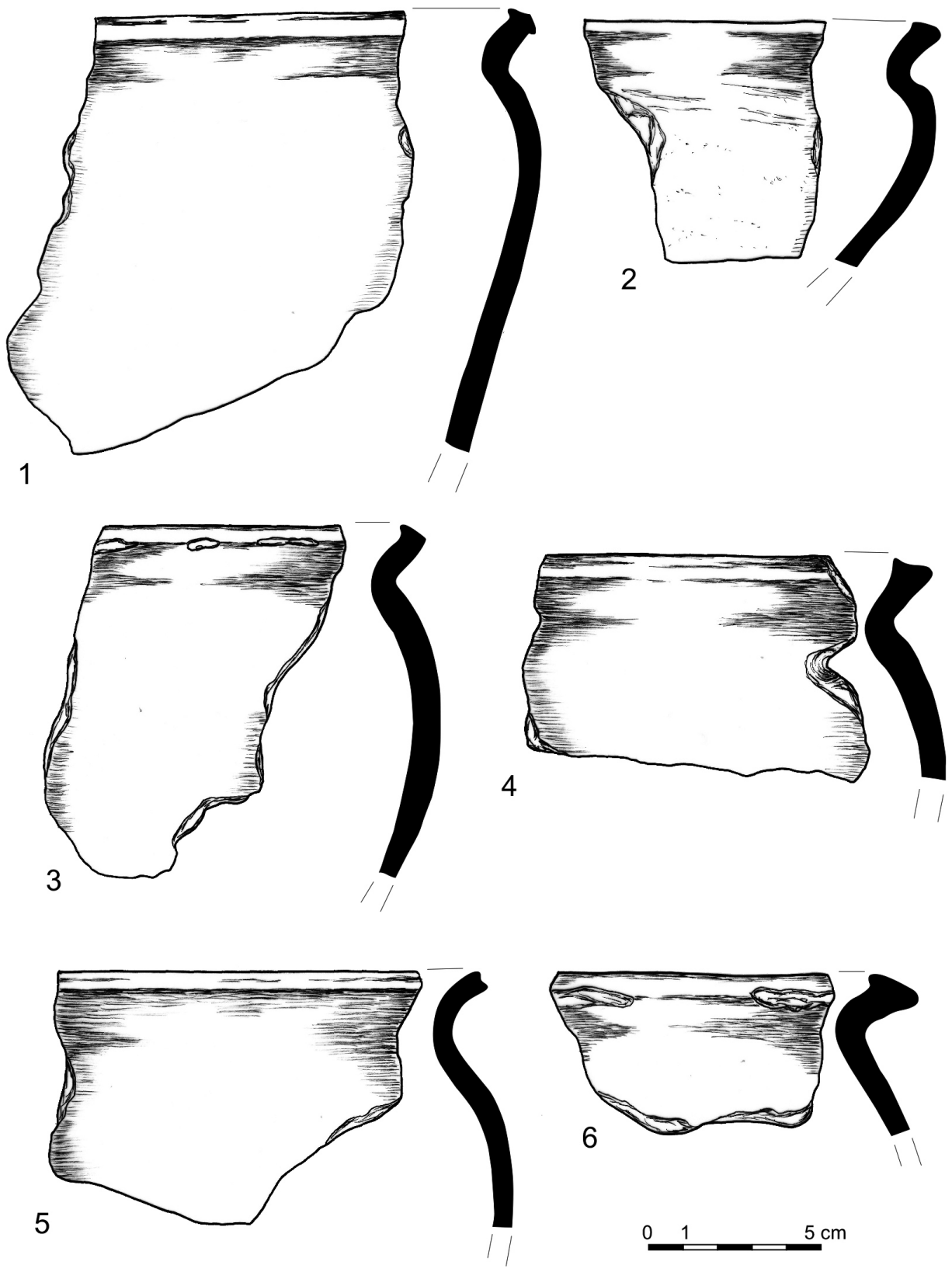

Ryc. 10. Mierczyce, woj. dolnośląskie. Przykłady naczyń nieornamentowanych o gładkich ściankach i silnie profilowanych wylewach (rys. A. Pankiewicz) 
Sulechowa - Gruszka 2013, s. 407-408, ryc. 45, tab. 9-10; Zawady - Gruszka 2014, s. 82-83, 104-105, ryc. 2 i z Połupina - Gruszka 2016a, s. 177, ryc. 28).

Naczynia z Mierczyc, Starego Zamku i Będkowic w znakomitej większości należą do okazów niezdobionych (ryc. 9-12). Ich powierzchnia zewnętrzna jest starannie opracowana za pomocą obtaczania górnej części naczynia i pieczołowitego wygładzania reszty korpusu. Ponieważ wygładzanie odbywało się już po częściowym podsuszeniu wyrobu, w znacznym stopniu ograniczało to możliwość naniesienia ornamentu, ale poprawiało szczelność naczyń (Stoksik i Paternoga 2009). Paleta barw wypału naczyń, często ograniczająca się do odcieni ciemnoszarych i czarnych, świadczy o preferowaniu określonych (redukcyjnych) warunków wypału przez garncarzy. Opisywane naczynia zostały zaliczone do grupy ceramiki „gładkiej”, typowej dla całego obszaru południa Dolnego Śląska. Prezentują bardzo jednolity, wysoki standard, który zdominował produkcję garncarską tego terenu na ponad 100 lat, gdyż ceramika „gładka” jest datowana ramowo na IX i pierwszą połowę X wieku.

Próbując uchwycić ów moment pojawienia się obtaczanych naczyń wysokiej jakości na południu Dolnego Śląska, stajemy niestety przed problemem niedokładnego datowania zespołów, których funkcjonowanie mogłoby przypadać na ten czas. Przyczyną tego jest niedobór stanowisk, których ramy chronologiczne zamykają się w VII-VIII wieku. Nieznajomość cech ceramiki VIII-wiecznej nastręcza także trudności w identyfikacji materiałów z drugiej połowy VIII i pierwszej połowy IX wieku. Dzięki względnie dobremu rozpoznaniu stylistyki wyrobów ceramicznych z X-XI w., nielicznym zespołom, z którymi możemy skorelować daty dendrochronologiczne, a także stanowiskom, na których odkryto tzw. zabytki wydzielone (głównie metalowe), znacznie lepiej rozpoznane są standardy garncarstwa z drugiej połowy IX i pierwszej połowy X w. (Pankiewicz 2012, s. 93-104). Spośród precyzyjniej datowanych stanowisk z południowej części Dolnego Śląska, których chronologia przypada właśnie na drugą połowę IX i pierwszą połowę X w., wymienić można: Gilów (schyłek IX i początek X w. - datowanie na podstawie daty dendrochronologicznej ze schyłku IX w. i licznych zabytków w typie wielkomorawskim), Legnicę (chronologia względna na podstawie sekwencji nawarstwień od drugiej połowy IX w. do schyłku wczesnego średniowiecza), Grodziszcze koło Świdnicy (datowanie na podstawie zespołów ceramiki od drugiej połowy IX do drugiej połowy X w.) i Niemczę (daty dendrochronologiczne oraz sekwencja nawarstwień od okresu sprzed połowy X wieku). Cechą wspólną tych stanowisk jest występowanie ceramiki „gładkiej”, zdecydowanie dominującej w zespołach z drugiej połowy IX w., mniej licznej w pierwszych dekadach X w., a już tylko sporadycznie występującej około połowy tego stulecia (por. Pankiewicz 2012, s. 93-103). Symptomatyczne, że na stanowiskach tych, choć brzegi naczyń „gładkich” należały czasem do mocno rozwiniętych, nie stwierdzono już okazów najsilniej profilowanych i pogrubionych, znanych właśnie z wzmiankowanych stanowisk w Mierczycach, Będkowicach i Starym Zamku. Z Mierczyc znane są też naczynia słabo 


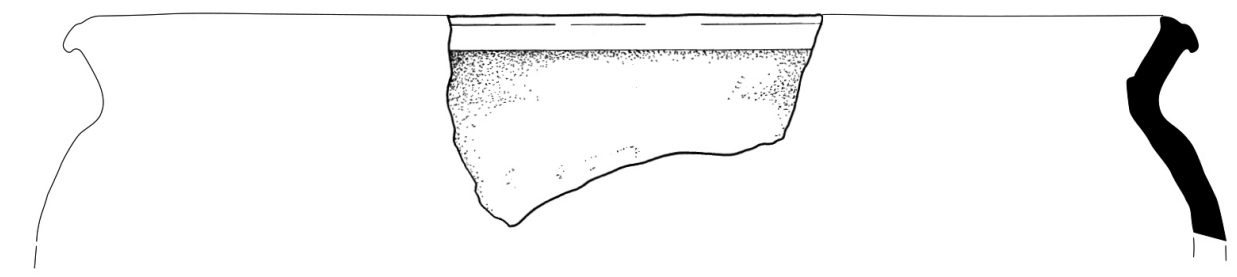

1

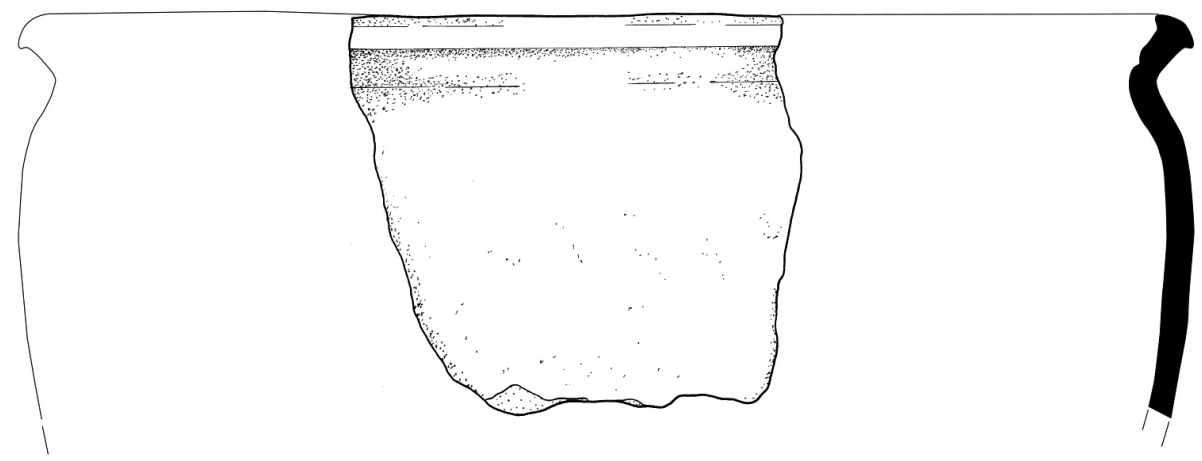

2

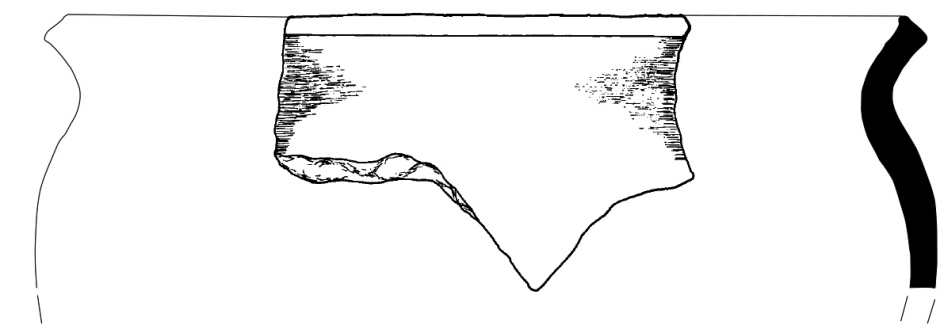

3

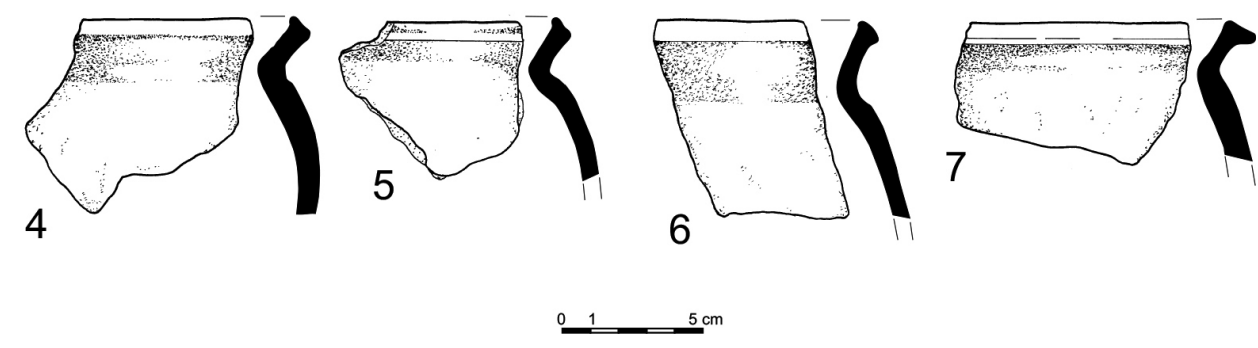

Ryc. 11. Będkowice, woj. dolnośląskie. Przykłady naczyń nieornamentowanych o gładkich ściankach i silnie profilowanych wylewach (rys. A. Pankiewicz) 
obtaczane, zdobione niezbyt udolnym ornamentem, wiązanym raczej ze stylistyką VIII-wieczną (Pankiewicz 2012, tabl. 84). Dawniej początki osadnictwa w Mierczycach, Starym Zamku i Będkowicach datowano jeszcze na wiek VIII. W toku późniejszych analiz tak wczesna chronologia została podana w wątpliwość i, jak stwierdzono, stanowiska rozwijały się w IX w., ze wskazaniem na jego pierwszą połowę (Pankiewicz 2012, s. 90-95), jednak problemem pozostaje nadal ustalenie początków ich funkcjonowania.

Oprócz cech mikromorfologicznych i mikroskopowych mas garncarskich ceramiki gładkiej, pewne zbieżności stylistyczno-formalne naczyń pochodzących z obu omawianych stref są widoczne także w niektórych formach zdobionych motywami wielokrotnych linii falistych wykonanych grzebykiem. Tak ornamentowane egzemplarze występują na wielu dolnośląskich stanowiskach (np. ryc. 13) w okresie IX i X w. i zazwyczaj stanowią około 20-30\% wszystkich odkrytych egzemplarzy (Pankiewicz 2012, s. 97). Na północy regionu tak zdobione garnki występują przede wszystkim w IX wieku. Z Sulechowa, stan. 28, pochodzi jedno takie naczynie oraz kilka większych fragmentów wylewów i brzuśców (ryc. 14; 15:1-5). Zrekonstruowany w całości egzemplarz, odkryty w obiekcie 40, to forma esowata, z dosyć silnie wydętym brzuścem umieszczonym około $2 / 3$ wysokości naczynia, z wyraźnie zaznaczoną szyjką (ryc. 14). Powierzchnia zewnętrzna jest lekko wygładzona, koloru szaro-brązowego (ryc. 14:2). Naczynie zostało ozdobione potrójnym pasmem wielokrotnej linii falistej. Jest to forma wykonana $\mathrm{z}$ wysoko plastycznej, zażelazionej gliny schudzanej specjalnie w tym celu przygotowanym drobnoziarnistym tłuczniem kwarcowo-skaleniowym z niewielkim dodatkiem skał granitoidowych oraz piaskiem pochodzenia fluwioglacjalnego. Zaobserwowano także, że w strefach peryferycznych obu powierzchni występuje jaśniejsza glinka będąca śladem angobowania wyrobu. Ponadto w partiach tych tło ilaste ma strukturę drobnowłókienkową, co może świadczyć o dosyć silnym obtaczaniu lub wygładzaniu wyrobu przed naniesieniem ornamentu. Wypał naczynia odbywał się w temperaturze około $600^{\circ} \mathrm{C}$, w warunkach redukcyjnych, a pod sam koniec procesu w atmosferze utleniającej (Gunia 2013a, s. 484).

Dalsze przykłady analogicznie zdobionych naczyń znaleziono także w obiekcie 40. Są to głównie fragmenty silnie wychylonych wylewów, ustawionych prostopadle do osi pionowej naczynia. Pochodzą one od naczyń o wygładzanych powierzchniach zewnętrznych (ryc. 15:1-4). Do ich produkcji użyto wysoko plastycznej gliny, która nie była praktycznie schudzana (Gunia 2013a, s. 470-471).

Ostatnie naczynie z tego stanowiska, zdobione wielokrotną linią falistą wykonaną grzebykiem odkryto w obiekcie 81 (ryc. 15:5). Jest to egzemplarz o esowatym profilu z dosyć silnie wychylonym wylewem i brzuścem umieszczonym około połowy wysokości naczynia. Powierzchnia zewnętrzna jest wygładzona. Ornament poczwórnej linii falistej pokrywa całą górną partię naczynia - od załomu po szyjkę. Do wykonania naczynia użyto silnie zażelazionej, plastycznej gliny, którą schudzono bardzo drobnym tłuczniem, przeważnie kwarcowym z dodatkiem piasku 

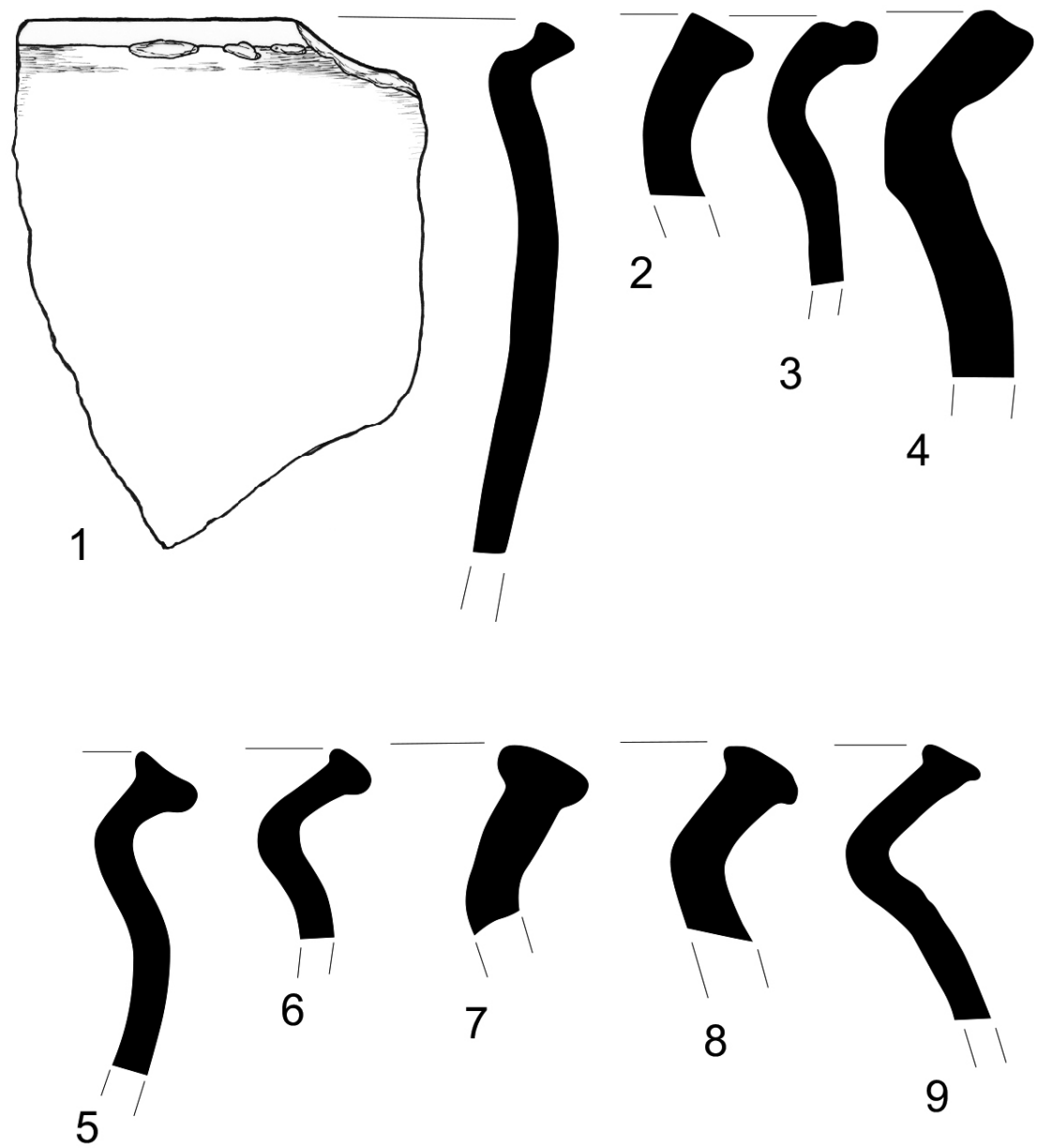

Ryc. 12. Stary Zamek, woj. dolnośląskie. Przykłady naczyń nieornamentowanych, o gładkich ściankach i silnie profilowanych wylewach (rys. A. Pankiewicz)

pochodzenia wodnolodowcowego i drobnoziarnistego materiału ze zwietrzałych granitoidów. Jednak masa garncarska nie była starannie wymieszana (Gunia 2013a, s. 490). W Połupinie naczynia zdobione występowały rzadko (ok. 8,5\% wszystkich analizowanych fragmentów), a ornamentowane wielokrotnymi liniami falistymi spotykamy w jednostkowych przypadkach (ryc. 15:6; zob. też Gruszka 2016a, ryc. 28).

Warto jeszcze wspomnieć o naczyniach odkrytych na grodzisku w Nowińcu, stan. 2 (ryc. 16). Sa to egzemplarze o esowatych profilach, starannie zdobione 
falistymi motywami grzebykowymi (grupa ornamentacyjna II, III, IV, X - por. Gruszka 2012, s. 50, 52-53, ryc. 2, tab. 1) i doskonale obtoczone na kole garncarskim. Do ich produkcji wykorzystywano masy ceramiczne intencjonalnie schudzane przede wszystkim ostrokrawędzistym tłuczniem kwarcowym (do $2 \mathrm{~mm}$ średnicy), skaleniami i rzadziej piaskiem rzecznym. Niekiedy jako składniki domieszki występowały minerały ciemne, np. pirokseny (Gunia 2012a, s. 271). Powierzchnie naczyń są lekko szorstkie lub gładkie, czasami noszą ślady angobowania.

W kontekście funkcjonowania na omawianym obszarze wyspecjalizowanych pracowni garncarskich można rozpatrywać odkrycie w obiekcie 53 na stan. 28 w Sulechowie fragmentu doskonale wykonanego naczynia o esowatym profilu i charakterystycznej fakturze powierzchni zewnętrznej, tzw. gęsiej skórki (ryc. 17:1). Wykonano je z plastycznej gliny schudzonej drobnym, ale słabo wysortowanym tłuczniem granitoidowym pochodzącym ze zwietrzałych głazów narzutowych. Jako domieszkę zastosowano tu także niewielką ilość drobnego, ostrokrawędzistego tłucznia kwarcowego. Wypał naczynia odbywał się w warunkach utleniających, w temperaturze około $650^{\circ} \mathrm{C}$ (Gunia 2013, s. 482). Opisywane naczynie jest zdobione w górnej partii brzuśca ornamentem precyzyjnej linii falistej wykonanej grzebykiem, poniżej której występuje motyw krokwiasty ograniczony od dołu dookolnym żłobkiem.

Analogiczne przykłady, poczynając od doskonałego wykonania, poprzez formę, ukształtowanie charakterystycznego kulkowatego wylewu, a kończąc na sposobie zdobienia oraz opracowaniu powierzchni, odnajdujemy wśród przedwojennych znalezisk z grodzisk w Klenicy, stan. 3 oraz Popęszycach, a także w Bonikowie, stan. 1 (Hilczerówna 1967, ryc. 55). Według Zofii Kurnatowskiej występowanie bardzo podobnych pod względem formalnym i stylistycznym naczyń jest śladem działalności wyspecjalizowanej pracowni garncarskiej, której wyroby rozchodziły się na niewielkim, ograniczonym obszarze (Hilczerówna 1967, s. 242).

Nieco inne światło na kwestię mikroregionalnej dystrybucji owych naczyń rzuca odkrycie zbliżonego egzemplarza na grodzisku w Gilowie (ryc. 17:2), na przedpolu Gór Sowich. Naczynie wykonane jest z typowej dla stanowiska masy garncarskiej, zawierającej drobnoziarnistą, wyselekcjonowaną domieszkę. Także forma, reprezentująca wariant naczynia o esowatym profilu z krótką szyjką, wysoko posadowionym załomem brzuśca i mocniej wychylonym wylewem, jest typowa dla południa Dolnego Śląska (formy A1, A2 wg Pankiewicz 2012, s. 40-42, 78-79, ryc. 3, 4). Znacznie rzadziej takie typy morfologiczne pojawiają się w zespołach naczyń z rejonu środkowego Nadodrza (por. np. Gruszka 2010a, s. 127-129, ryc. $10-11$; 2012, s. 58-66, ryc. 5-10; 2013, s. 396-401, ryc. 39-42, tab. 8; 2014, s. 87-93, ryc. 5-9; 2016a, s. 164-172, ryc. 14-20). Jak już wspominano, rzadko spotykana $\mathrm{w}$ środowisku podsudeckim jest natomiast ornamentyka naczynia $\mathrm{z}$ Gilowa, wykorzystująca wątki grzebykowe linii falistych i pionowych, nieciągłych pasm prostych. Samo zdobienie, poza przytoczonymi analogiami z Sulechowa, Klenicy, Popęszyc i Bonikowa, wpisuje się raczej w nurt ornamentyki z północnej 

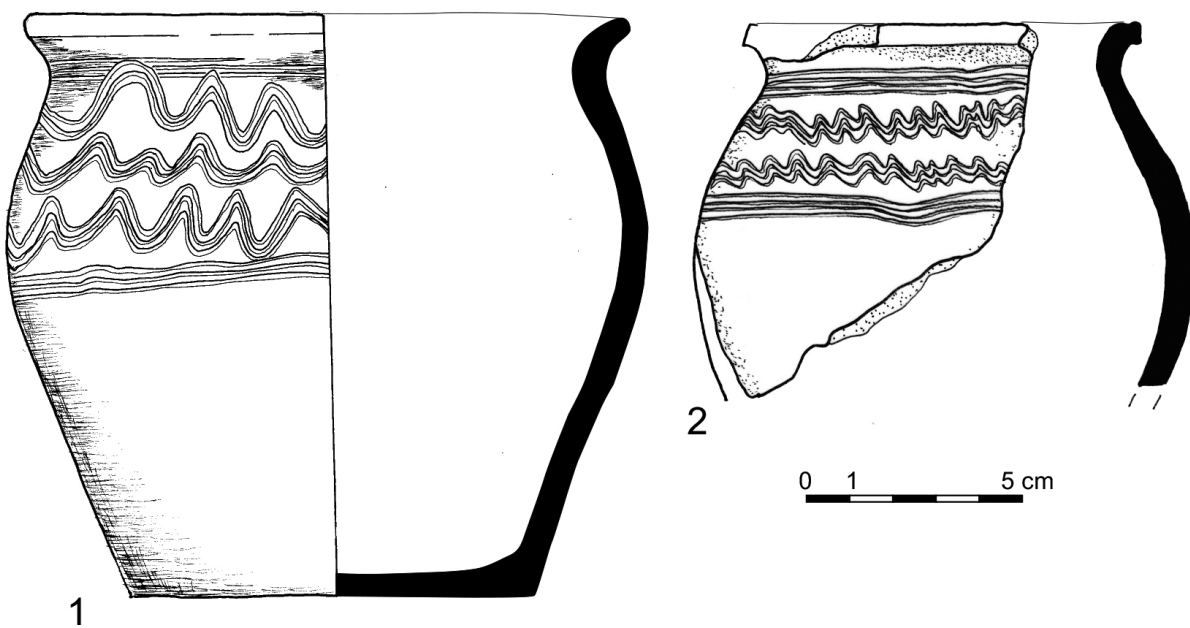

Ryc. 13. Przykłady naczyń z IX i X wieku występujących w południowej części Dolnego Śląska, zdobionych wielokrotnymi liniami falistymi wykonanymi grzebykiem:

1 - Mierczyce; 2 - Gilów (rys. A. Pankiewicz)

części Dolnego Śląska, powszechnie stosującej motywy grzebykowe w układach pionowych (por. fragment powyżej).

Okazy gilowski i sulechowski łączy jeszcze jedna, zdawałoby się drugorzędna cecha. Analiza mikroskopowa naczynia z Sulechowa wykazała, że cechą charakterystyczną tła ilastego tego wyrobu jest jego uporządkowana, kierunkowa tekstura wyrażona przez równolegle układające się systemy szklistych żyłek (Gunia 2013a, s. 482). Może to świadczyć o działaniu dosyć dużego ciśnienia na ściankę lepionego naczynia, czyli odwrotnie skierowanych dwóch wektorów siły - odśrodkowej powstałej podczas silnej rotacji koła garncarskiego i nacisku dłoni garncarza na lepioną ściankę naczynia.

Uporządkowana tekstura tła jest zjawiskiem dosyć rzadko spotykanym w naczyniach z IX i X w., a nawet nieco młodszych pochodzących z obszaru Dolnego Śląska czy pogranicza dolnośląsko-łużycko-wielkopolskiego. Oprócz omówionego powyżej naczynia z Sulechowa, do wyjątków można zaliczyć także cechujące się znacznym zaawansowaniem technologicznym naczynia z grodziska w Gilowie, gdyż niektóre z nich, zwłaszcza okazy określane jako silnie formująco obtaczane (por. Jaworski i Rzeźnik 1994, s. 320-323) odznaczają się kierunkowym układem masy garncarskiej (por. Łydżba-Kopczyńska i in. 2008, tab. 2). Warto odnotować, że uporządkowana, kierunkowa tekstura tła masy ilastej jest cechą typową naczyń 


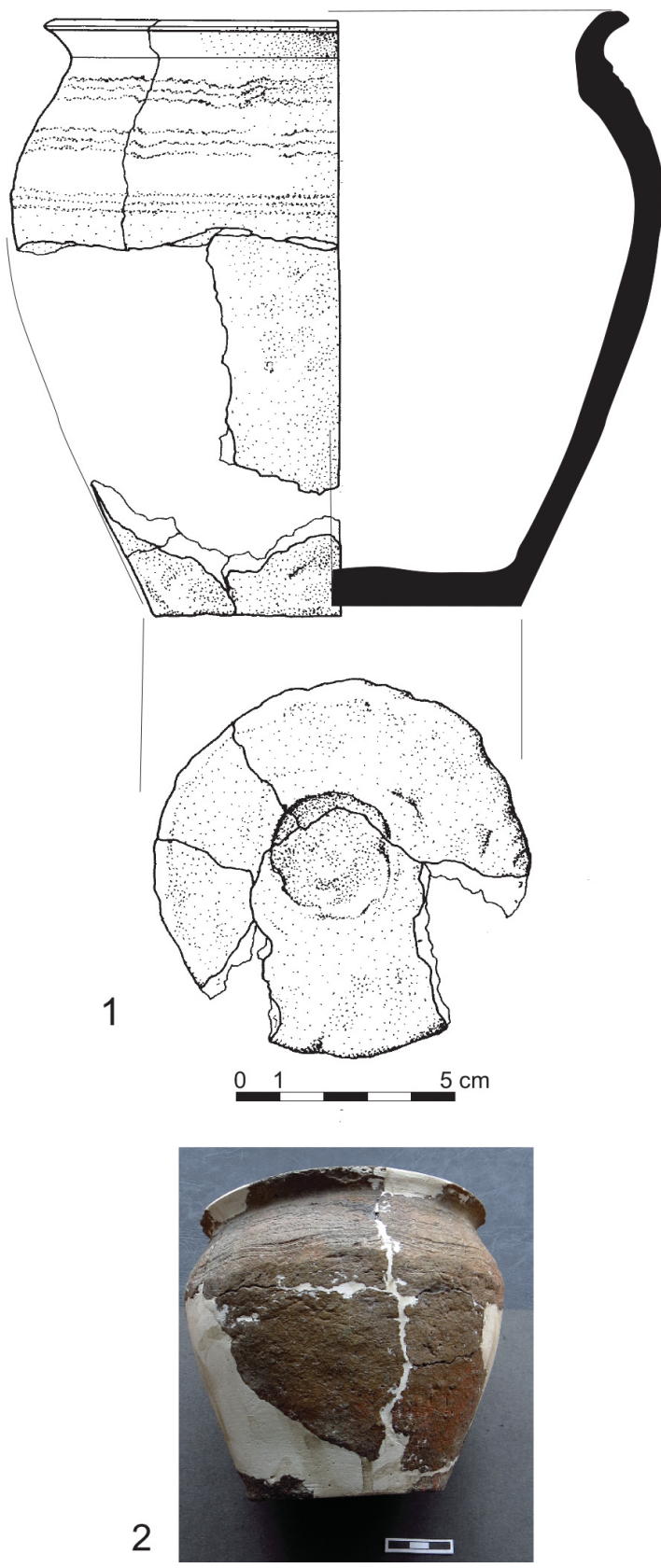

Ryc. 14. Sulechów, stan. 28, woj. lubuskie. Naczynie o esowatym profilu, zdobione w górnej partii brzuśca wielokrotną linią falistą wykonaną grzebykiem (obiekt 40) (rys. D. Krzyżyńska, fot. B. Gruszka) 


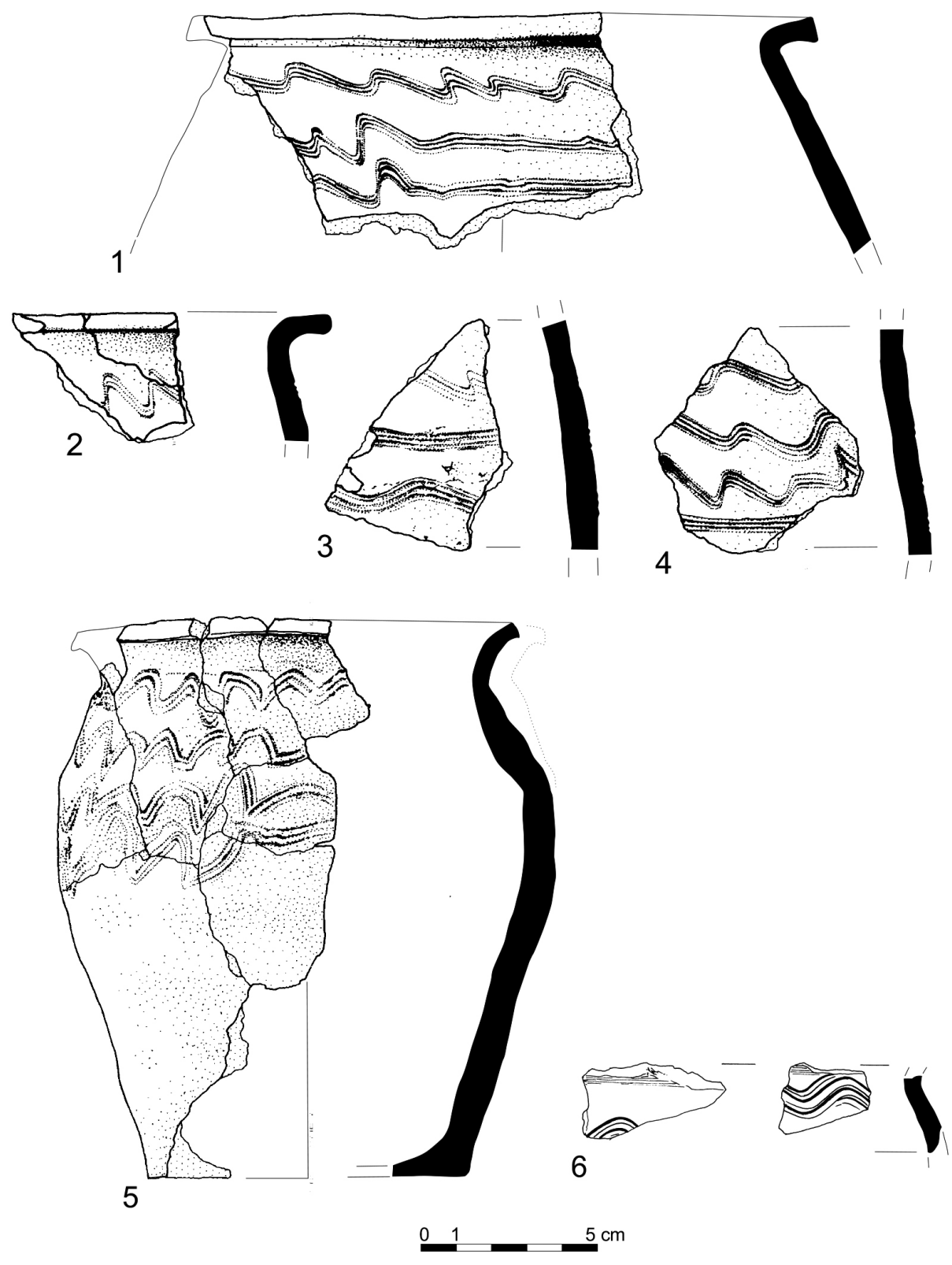

Ryc. 15. Przykłady naczyń zdobionych wielokrotną linią falistą wykonaną grzebykiem. Sulechów, stan. 28, woj. lubuskie:

1-4 - obiekt 40; 5 - obiekt 81; Połupin, stan. 2, woj. lubuskie: 6 - z północnego skłonu wału, z drugiego, niższego poziomu żwiru zalegającego pod warstwą gliny (nr inw. 103/61) (rys. D. Krzyżyńska, E. Pawlak) 

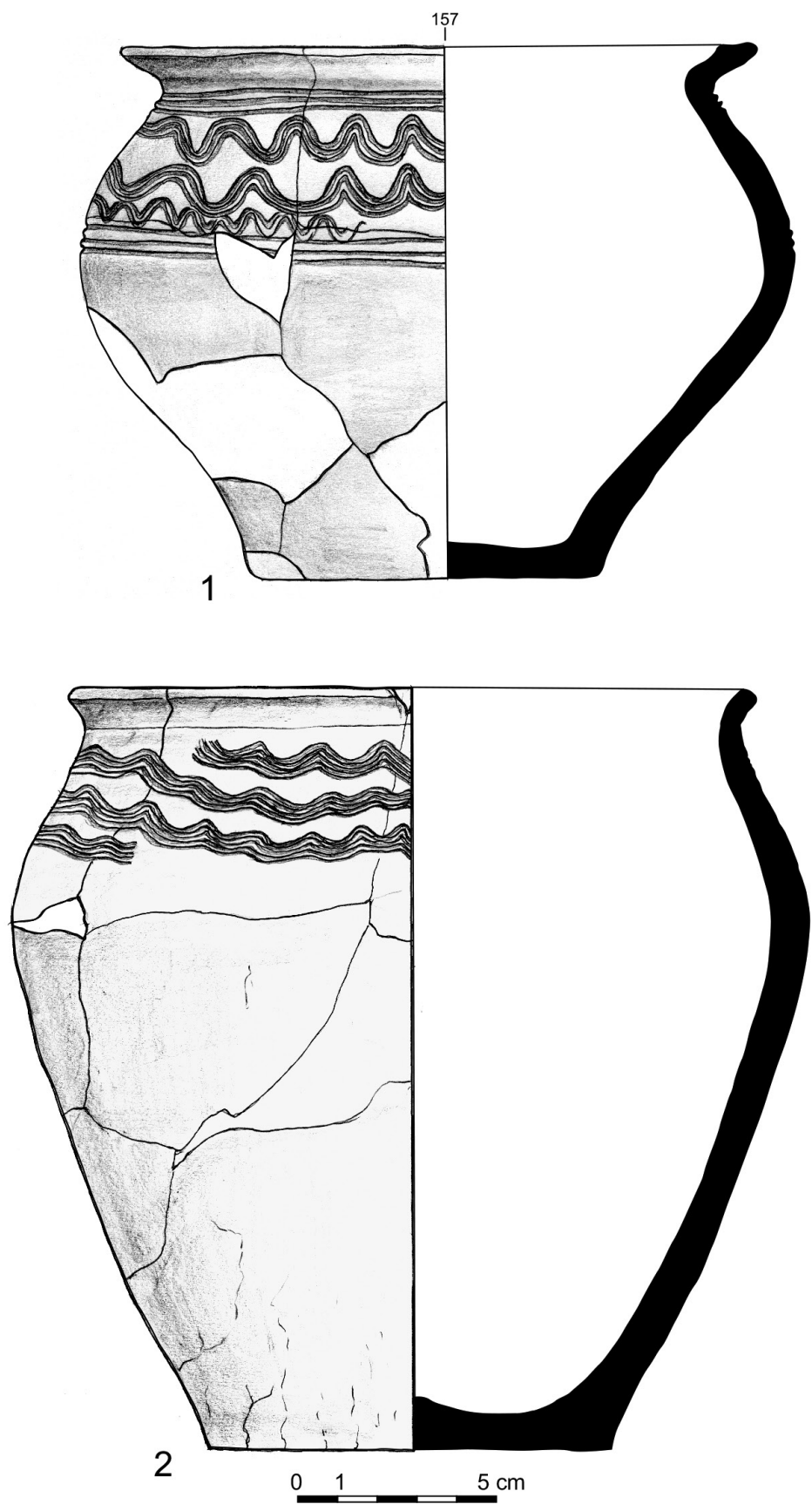

Ryc. 16. Nowiniec, stan. 2. Przykłady naczyń zdobionych wielokrotną linią falistą wykonaną grzebykiem (obiekt 17) (rys. S. Kałagate) 

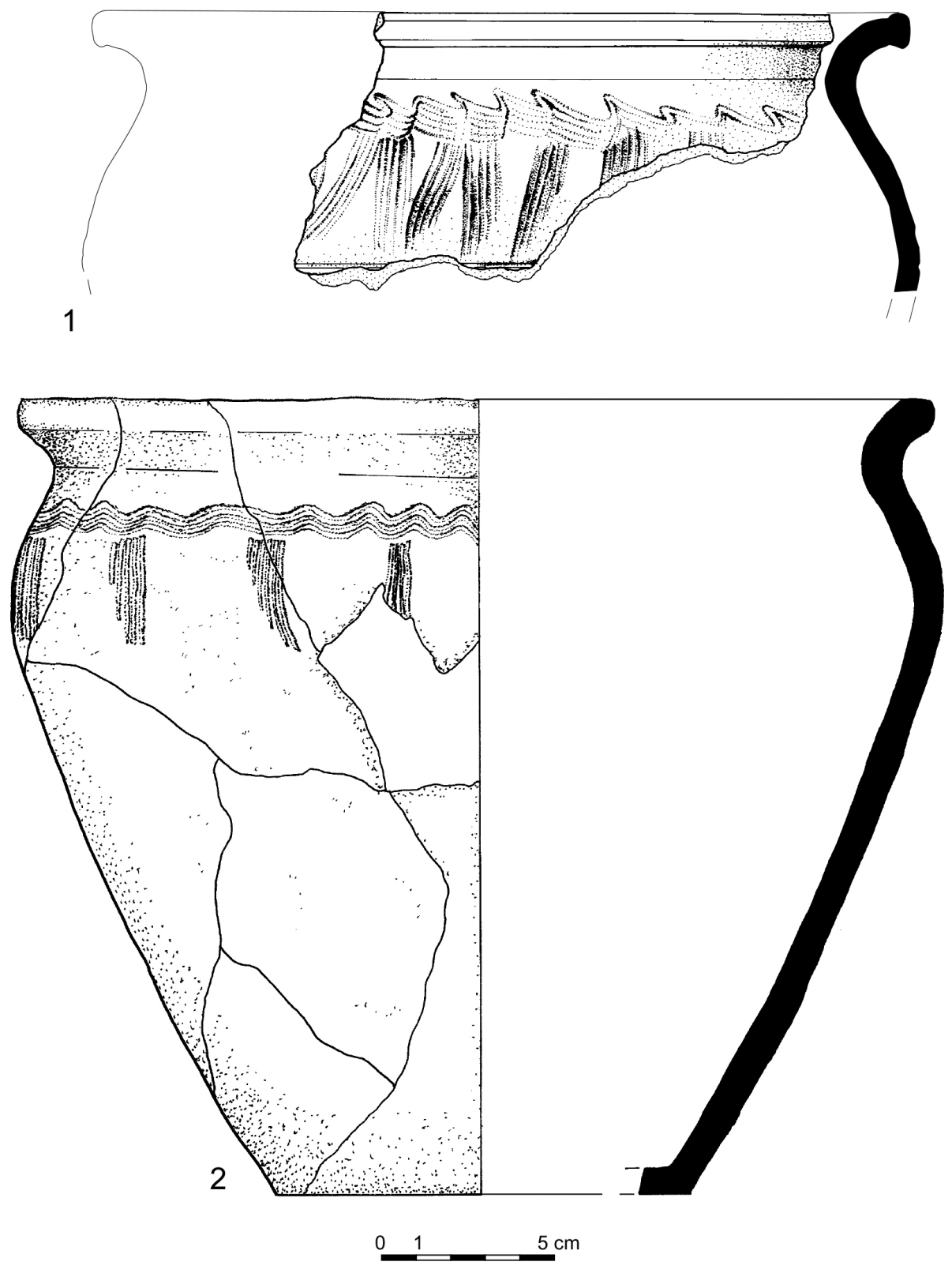

Ryc. 17. Przykłady naczyń zdobionych pionowymi, nieciągłymi pasmami grzebykowymi 1 - Sulechów, stan. 28, woj. lubuskie (obiekt 53); 2 - Gilów, woj. dolnośląskie (rys. D. Krzyżyńska, A. Pankiewicz) 
z młodszych odcinków chronologicznych wczesnego średniowiecza (zob. np. Stoksik 2007). Stwierdzone przykłady uporządkowanej tekstury tła masy ilastej w naczyniach można zatem wiązać z funkcjonowaniem wyspecjalizowanych pracowni garncarskich.

Problem pochodzenia omawianej grupy naczyń pozostaje jednak otwarty. Na obecnym etapie badań nie jesteśmy w stanie wskazać, czy wywodzą się one z pogranicza wielkopolsko-śląsko-łużyckiego, czy może są związane z południowymi obszarami Dolnego Śląska, czy też naczynia te łączą w sobie cechy tradycji garncarskich obu tych terenów? Odpowiedzi na te pytania mogą dostarczyć specjalistyczne badania petrograficzne i geochemiczne tych fragmentów naczyń.

W kontekście występowania omówionych powyżej naczyń warto zwrócić uwagę na przebieg procesu adaptacji koła garncarskiego na północnej rubieży obecnego Dolnego Śląska. Przeprowadzone szczegółowe badania dotyczące wykorzystywania koła garncarskiego do produkcji naczyń w starszych podokresach wczesnego średniowiecza na obecnej Ziemi Lubuskiej ${ }^{1}$ ukazały, że w VIII w. (raczej w jego drugiej połowie) doszło do skokowego przyrostu form obtaczanych (Gruszka 2016b, s. 240-241). Zmiana techniki produkcji naczyń miała charakter rewolucyjny, a nie ewolucyjny. Pomijając nieliczne, obtaczane formy datowane na początkowe stadia wczesnego średniowiecza (Gruszka i Kara 2013, s. 243, 245; Gruszka i in. 2013, s. 175), pojawienie się w drugiej połowie VIII i na początku IX w. egzemplarzy doskonale wykonanych przy użyciu koła garncarskiego, o obcych formach i stylistyce, poprzedza masowe występowanie naczyń obtaczanych, jednak wytwarzanych sposobem przydomowym. Warto jednak zwrócić uwagę, że młodsze egzemplarze, pojawiające się od połowy IX w., które można utożsamiać z naczyniami typu Tornow i Menkendorf, ustępują pod względem technologii, a także techniki wykonania opisywanym naczyniom o cechach wyspecjalizowanego garncarstwa.

\section{PODSUMOWANIE}

Podjęte studia porównawcze nad ceramiką z północnej i południowej części Dolnego Śląska wykazały szereg podobieństw niektórych typów naczyń występujących na obu obszarach. Do cech wspólnych można zaliczyć występowanie, zarówno na północy, jak i na południu, ceramiki niezdobionej o gładkiej, starannie opracowanej powierzchni. Dalsze analogie dotyczą ukształtowania wylewów, form i ornamentyki.

$\mathrm{Na}$ podstawie badań mikroskopowych wybranych ułamków naczyń z północy regionu (stanowiska w Sulechowie, Połupinie i Nowińcu) stwierdzono, że zawie-

\footnotetext{
${ }^{1}$ Badania były prowadzone w ramach projektu: Badania interdyscyplinarne nad wczesnośredniowiecznym (VII-X/XI wiek) warsztatem garncarskim $w$ dorzeczu środkowej Odry, finansowanego ze środków Narodowego Centrum Nauki (nr umowy: UMO- 2012/05/N/HS3/01425).
} 
rają one w składzie masy garncarskiej ziarna amfiboli lub piroksenów, które są charakterystyczne dla stanowisk strefy podsudeckiej. Biorąc pod uwagę podobieństwo zarówno technologiczne (zastosowanie drobnej domieszki), jak i stylistyczne (morfologia i ornamentyka) tych okazów, można uznać je za importy z południa. Kwestia obecności naczyń proweniencji północnej w podsudeckiej części Śląska ciągle pozostaje otwarta. Niektóre, nietypowe, elementy stylistyki garncarskiej tego obszaru mogą mieć genezę miejscową. Stylistyka innych może wynikać z wzajemnych powiązań kulturowych tych stref, potwierdzonych znaleziskami np. przedmiotów z surowców skalnych o południowej genezie, które odkryto w rejonie Sulechowa, Zawady i Klenicy (Lisowska i in. 2014; Gruszka 2010, s. 143-145), czy paciorków o nawiązaniach południowych, które wystąpiły na grodziskach w Połupinie (Sawicka 2016, s. 109, ryc. 1) i w Gostchorzu (Gruszka i in. 2015, s. 30, 32 , ryc. 5).

Symptomatyczne jest to, iż gros cech wspólnych rozpoznanych w ceramice z obu stref dotyczy zespołów wczesnych z pierwszej połowy IX, być może nawet z drugiej połowy VIII wieku. Na ten właśnie okres są datowane stanowiska w Sulechowie, Połupinie, zapewne także w Mierczycach i Będkowicach. W mniejszym stopniu podobieństwo to dotyczy stanowisk nieco późniejszych, których chronologia przypada na drugą połowę IX i początki X wieku (np. Gilów, Nowiniec). W późniejszym okresie analogie dotyczą już pojedynczych egzemplarzy naczyń, nie zaś poszczególnych ich typów, rodzajów wylewów i zdobień.

Nieraz zwracano uwagę na różnice pomiędzy garncarstwem północnych i południowych terenów Dolnego Śląska. Przy czym zdaniem badaczy miały one dotyczyć już zespołów z najstarszych stanowisk wczesnośredniowiecznych tych obszarów. Jak podkreślano, formy naczyń południowych miały się odznaczać smukłą budową i większą precyzją wykonania ornamentyki. Wpisywać się one miały $\mathrm{w}$ nurt szeroko rozumianej strefy praskiej, następnie popraskiej i przez kolejne stulecia wykazywać więcej związku z garncarstwem obszarów położonych na południe od Sudetów. Naczynia „północne” charakteryzowano jako przysadziste, często obejmujące formy określane jako wazowate. Miały one odznaczać się mniej starannym zdobieniem i mniej dbałym opracowaniem powierzchni. Takie okazy miały mieścić się w kanonach wytwórczości strefy Sukow (krótkie podsumowanie wiedzy na ten temat - Wachowski 1997, s. 86-95, ryc. 58-69). Ten znacznie uproszczony schemat nie oddaje jednak dynamiki przemian garncarstwa śląskiego.

W świetle przeprowadzonych badań wydaje się, że występowanie cech wspólnych zaobserwowanych $w$ ceramice $z$ północnych i południowych partii Śląska wynika z kilku przyczyn. U schyłku VIII i w początkach IX w. zespoły reprezentujące obie strefy kulturowe dopiero się różnicują. W obu mikroregionach dominuje nadal ceramika niezdobiona o formach esowatych. Sądzimy, że pojawienie się w tym czasie bardzo rozwiniętych form wylewów może być wynikiem oddziaływań obcych, zarówno na tereny północne, jak i południowe. Rozliczne zbieżności, nawet bardzo szczegółowe, dotyczące wykończenia naczyń wskazują natomiast wy- 
raźnie na to, że jeszcze co najmniej w pierwszej połowie IX w. garncarze śląscy dzielili się doświadczeniami, a między ludnością zamieszkującą północ i południe dokonywała się wymiana, która oprócz innych wyrobów dotyczyła także pojemników ceramicznych. Owa różnokierunkowa, obejmująca bowiem zarówno lokalne, jak i ponadlokalne idee, wymiana doświadczeń w dziedzinie produkcji garncarskiej zaowocowała znacznym rozwojem wytwórstwa naczyń ceramicznych w tym okresie, przejawiającym się między innymi dużym zróżnicowaniem stylistyki i form.

Sytuacja ta zmienia się zdecydowanie $\mathrm{w}$ drugiej połowie IX i początkach $\mathrm{X}$ wieku. Mimo że $\mathrm{z}$ tego czasu znamy także pojedyncze przykłady nawiązań do północnego, i przeciwnie południowego, garncarstwa, jest to jednak okres funkcjonowania w poszczególnych mikroregionach określonych typów ceramiki - ,gładkiej" na południu i ceramiki typu Tornow, wraz z jej derywatami, na północy omawianego obszaru. Wytwórczość garncarska staje się dość hermetyczna, co przejawia się nie tylko polaryzacją odmiennych trendów stylistycznych na północy i na południu Śląska, ale także ograniczoną podatnością środowisk lokalnych na oddziaływania zewnętrzne. Przykładowo w strefie wyżynnej Śląska, w której doszukiwano się materialnych śladów kontaktów tych ziem z terenami Moraw i Czech, stwierdzono faktyczne wpływy zza Sudetów i Karpat na rodzimą wytwórczość, ale ograniczone jedynie do wybranych punktów/enklaw osadniczych. Nie przekładały się one natomiast na ogół produkcji garncarskiej (por. Pankiewicz 2012, s. 263-265). Z kolei w przypadku strefy północnej naczynia zaliczane do typu Tornow występowały na dużym, jednak dosyć ściśle określonym obszarze, a co bardziej istotne, technologia $i$ technika ich produkcji była znacznie mniej zaawansowana niż w przypadku części naczyń z okresu wcześniejszego i nosiła znamiona produkcji przydomowej. Zatem w drugiej połowie IX i początkach X w., choć mamy już do czynienia $\mathrm{z}$ w pełni wykształconymi standardami garncarstwa, obserwujemy na całym obszarze dolnośląskim pewnego rodzaju regres, objawiający się na przykład w zaniku najbardziej rozbudowanych form wylewów.

Obserwacja analogii w ceramice, nawet w skali lokalnej, wzbogacona wynikami badań specjalistycznych, dostarcza zatem szeregu spostrzeżeń na temat dynamiki rozwoju garncarstwa w poszczególnych mikroregionach, adaptacji wzorców obcych, a także ogólnych obserwacji dotyczących oblicza kulturowego Śląska w różnych okresach. Studia nad ceramiką mają w sobie wciąż ogromny, a nadal jeszcze niewykorzystany potencjał $\mathrm{w}$ badaniach przeszłości.

\section{LITERATURA}

August C. 2008, Analiza mineralogiczno-petrograficzna ceramiki, załącznik do pracy A. Pankiewicz, Relacje kulturowe poludniowego Śląska i pótnocnych Czech i Moraw w IX-X wieku w świetle źródet ceramicznych, Wrocław 2008, maszynopis pracy doktorskiej, przechowywany w archiwum Instytutu Archeologii Uniwersytetu Wrocławskiego. 
Biermann F., Kieseler A. i Nowakowski D. 2011, Mittelalterische Herrschafts- und Siedlungsurtkturen in Niederschlesien am Beispiel von Köben (Chobienia) an der Oder, „Praehistorishe Zietschrift“, t. 86 , s. $100-132$.

Bojarski J. 2012, Wczesnośredniowieczny mikroregion osadniczy w Napolu na ziemi chetmińskiej. Wytwórczość garncarska jako źródło poznania lokalnych procesów osadniczych, Torun.

Dębski A. 2014, Wczesnośredniowieczna osada w Wilenku, gm. Szczaniec, wraz z pozostałościami osadnictwa nowożytnego. Archeologiczne badania ratownicze na trasie autostrady A2, w: Via Archaeologica Posnaniensis, Źródła archeologiczne z badań wykopaliskowych na trasach dróg $i$ autostrad, red. M. Kobusiewicz i in., t. 10, Poznań.

Gruszka B. 2010, Wczesnośredniowieczna osada przygrodowa (podgrodzie?) w Klenicy (stan. 4), pow. zielonogórski. Opracowanie wyników badań z 1962 r., „Archeologia Środkowego Nadodrza”, t. 7, s. 109-190.

- 2012, Wczesnośredniowieczne zabytki ceramiczne ze stan. 2 w Nowińcu, gm. Lubsko, woj. lubuskie w ujęciu stylistyczno-technologicznym, w: Nowiniec, stan. 2. Wczesnośredniowieczny gród na pograniczu śląsk-lużyckim $w$ świetle badań interdyscyplinarnych, red. B. Gruszka, Zielona Góra, s. 47-129.

- 2013, Wczesnośredniowieczna osada na stanowisku 28 w Sulechowie, w: Obwodnica Sulechowa, woj. lubuskie. Badania archeologiczne na stanowiskach 10, 25, 26, 27, 28, t. 1, red. B. Gruszka, A. Jaszewska i S. Kałagate, Zielona Góra, s. 365-454.

- 2014, Zabytki ceramiczne ze stanowiska 1 w Zawadzie, gm. Zielona Góra w ujęciu stylistyczno-technologicznym, w: Wczesnośredniowieczna osada z Zawadzie, stan. 1, gm. Zielona Góra. Studia interdyscyplinarne, red. B. Gruszka, Zielona Góra, s. 81-167.

- 2015, Znaleziska ceramiczne z wczesnośredniowiecznej osady w Mozowie, stan. 23. Analiza stylistyki, formy, techniki wykonania i chronologii, w: Osada z połowy VII i poczatku VIII wieku w Mozowie, stan. 23, woj. lubuskie. Źródła archeologiczne i środowiskowe, red. B. Gruszka, Monografie wczesnośredniowieczne, t. 1, Zielona Góra, s. 85-136.

- 2016a, Znaleziska ceramiczne z badań wczesnośredniowiecznego grodu w Polupinie, stan. 2. Chronologia oraz analiza stylistyki, formy i techniki wykonania, w: Wczesnośredniowieczny gród w Potupinie, stan. 2. Nowe analizy i interpretacje źródeł archeologicznych i przyrodniczych, red. B. Gruszka, Monografie wczesnośredniowieczne, t. 2, Zielona Góra, s. 143-238.

- 2016b, Próba określenia chronologii grodu w Polupinie na podstawie wyników analizy porównawczej źródel archeologicznych i oznaczén wieku metoda ${ }^{14} C$, w: Wczesnośredniowieczny gród $w$ Potupinie, stan. 2. Nowe analizy $i$ interpretacje źródeł archeologicznych i przyrodniczych, red. B. Gruszka, Monografie wczesnośredniowieczne, t. 2, Zielona Góra, s. 239-244.

Gruszka B. i Kara M. 2013, Wybrane znaleziska ceramiki o cechach warsztatowych ze starszych faz wczesnego średniowiecza z południowo-zachodniej Wielkopolski i poludniowo-wschodniej części Ziemi Lubuskiej w świetle badań specjalistycznych, „Slavia Antiqua”, t. 54, s. 241-265.

Gruszka B., Pawlak E. i Pawlak P. 2013, Zespoły ceramiczne ze starszych faz wczesnego średniowiecza na wybranych stanowiskach środkowego Nadodrza w świetle najnowszych wyników datowań przyrodniczych, „Archeologia Polski”, t. 58, z. 1-2, s. 171-198.

Gruszka B., Forysiak J., Twardy J., Kałagate S. 2015, Goskar - grodzisko w Gostchorzu, Krosno Odrzańskie.

Gunia P. 2012a. Wyniki badań petrograficznych zabytków ceramicznych z wczesnośredniowiecznego grodziska w Nowińcu, stan. 2, gm. Lubsko, woj. lubuskie, w: Nowiniec, stan. 2. Wczesnośredniowieczny gród na pograniczy śląsko-tużyckim $w$ świetle badań interdyscyplinarnych, red. B. Gruszka, Zielona Góra, s. 235-339.

- 2012b, Wyniki badań geochemicznych ceramiki z wczesnośredniowiecznego grodziska w Nowińcu, stan. 2, gm. Lubsko, woj. lubuskie, w: Nowiniec, stan. 2. Wczesnośredniowieczny gród na pograniczy ślasko-łużyckim w świetle badań interdyscyplinarnych, red. B. Gruszka, Zielona Góra, s. 341-358.

- 2013a, Wyniki badań petrograficznych ceramiki ze stanowiska 28 w Sulechowie (Aneks 1), w: Obwodnica Sulechowa, woj. lubuskie. Badania archeologiczne na stanowiskach 10, 25, 26, 27, 28, t. 1, Biblioteka Archeologii Środkowego Nadodrza, z. 6, red. B. Gruszka, A. Jaszewska i S. Kałagate, Zielona Góra, s. 467-551. 
- 2013b, Wyniki badań petrograficznych ceramiki ze stanowiska 10 w Sulechowie (Aneks 1), w: Obwodnica Sulechowa, woj. lubuskie. Badania archeologiczne na stanowiskach 10, 25, 26, 27, 28, t. 1, Biblioteka Archeologii Środkowego Nadodrza, z. 6, red. B. Gruszka, A. Jaszewska i S. Kałagate, Zielona Góra, s. 191-269.

- 2013c, Wyniki badań geochemicznych wczesnośredniowiecznej ceramiki z osady w Sulechowie, stan. 28, w: Obwodnica Sulechowa, woj. lubuskie. Badania archeologiczne na stanowiskach 10, 25, 26, 27, 28, t. 1, Biblioteka Archeologii Środkowego Nadodrza, z. 6, red. B. Gruszka, A. Jaszewska i S. Kałagate, Zielona Góra, s. 523-537.

- 2014a, Wyniki badań petrograficznych ceramiki ze stanowiska 1 w Zawadzie, gm. Zielona Góra, w: Wczesnośredniowieczna osada w Zawadzie, stan. 1, gm. Zielona Góra. Studia interdyscyplinarne, red. B. Gruszka, Zielona Góra, s. 289-342.

- 2014b, Wyniki badań geochemicznych wczesnośredniowiecznej ceramiki z osady w Zawadzie, gm. Zielona Góra, w: Wczesnośredniowieczna osada w Zawadzie, stan. 1, gm. Zielona Góra. Studia interdyscyplinarne, red. B. Gruszka, Zielona Góra, s. 343-366.

- 2016a, Wyniki badań petrograficznych wczesnośredniowiecznych naczyń z grodziska w Potupinie, stan. 2, w: Wczesnośredniowieczny gród w Polupinie, stan. 2. Nowe analizy i interpretacje źródet archeologicznych i przyrodniczych, red. B. Gruszka, Monografie wczesnośredniowieczne, t. 2, Zielona Góra, s. 255-307.

- 2016b, Wyniki badań geochemicznych wczesnośredniowiecznych naczyń z grodziska w Polupinie, stan. 2, w: Wczesnośredniowieczny gród w Polupinie, stan. 2. Nowe analizy i interpretacje źródet archeologicznych i przyrodniczych, red. B. Gruszka, Zielona Góra, s. 309-323.

Gunia P. i Gruszka B. 2010, Technologia i zaplecze surowcowe wczesnośredniowiecznej ceramiki użytkowej ze stanowiska 2 w Stożnem, woj. lubuskie w świetle badań petrograficznych, „Slavia Antiqua”, t. 51, s. 269-280.

- 2011, Technologia i zaplecze surowcowe wczesnośredniowiecznej ceramiki użytkowej ze stanowiska $4 w$ Klenicy $w$ świetle badań petrograficznych, w: Ogień - zywiol ujarzmiony $i$ nieujarzmiony. VI Polsko-Niemieckie Spotkania Archeologiczne, Garbicz, 5-6 czerwca 2008, red. A. Jaszewska i A. Michalak, Zielona Góra, s. 349-369.

Hilczerówna Z. 1967, Dorzecze górnej i środkowej Obry od VI do początków XI wieku, Wrocław-Warszawa-Kraków.

Jaworski K. i Rzeźnik P. 1994, Kontakty z Morawami i (lub) z Czechami około IX/X wieku w świetle nowych danych z badań w Gilowie w 1992 roku, „Śląskie Sprawozdania Archeologiczne”, t. 35, s. 307-327.

Kieseler A. 2016, Der slawische Burgwall von Kleinitz (Klenica) im nördlischen Niederschlesie, in: Burg, Herrschaft und Siedlung im mittelalterlichen Niederschlesien, ,Studien zur Archäologie Europas", t. 27, red. J. Henning, F. Biermann i J. Macháček, Bonn, s. 211-465.

Kobylińska U. 2014, Ceramika wczesnośredniowieczna ze st. 3 w Starosiedlu, w: Starosiedle w Ziemi Lubuskiej. Osadnictwo starożytne i wczesnośredniowieczne, red. Z. Kobyliński, Warszawa 2014, s. 521-568.

Łydżba-Kopczyńska B., Zych E., August C., Rusek G., Pankiewicz A. 2008, Identyfikacja pochodzenia ceramiki z IX i X wieku wydobytej na terenie Przedgórza Sudeckiego przy zastosowaniu badań fizykochemicznych, w: Nauka i zabytki. Nauki ścisłe w stużbie archeologii, ochronie zabytków oraz historii, Warszawa, s. 45-63.

Lisowska E., Gunia P. i Gruszka B. 2014, Przedmioty z surowców skalnych z wczesnośredniowiecznej osady w Zawadzie, stan. 1, w świetle wyników analiz petroarcheologicznych, w: Wczesnośredniowieczna osada w Zawadzie, stan. 1, gm. Zielona Góra. Studia interdyscyplinarne, red. B. Gruszka, Zielona Góra, s. 167-196.

Pankiewicz A. 2012, Relacje kulturowe poludniowego Śląska i pótnocnych Moraw i Czech w IX i X wieku $w$ świetle źródel ceramicznych, Wrocław.

Pokora H. i Rzeźnik P. 1998, Wznowienie badań wykopaliskowych na wczesnośredniowiecznej osadzie w Obiszowie, gm. Grębocice, „Śląskie Sprawozdania Archeologiczne”, t. 40, s. 321-333.

Pawlak P. 2012, Wczesnośredniowieczne osadnictwo na stanowisku nr 5 w Gościkowie, pow. świebodziński, „Archeologia Środkowego Nadodrza”, t. 9, s. 139-208. 
- 2013, Cmentarzysko cialopalne i osada ze starszego stadium wczesnego średniowiecza w Myszęcinie, w: Myszęcin stanowisko 19, województwo lubuskie. Od młodszej epoki kamienia po XX wiek, red. E. i P. Pawlakowie, Zielona Góra, s. 169-395.

Pawlak E. i Pawlak P. 2013, Osadnictwo wczesnośredniowieczne na stanowisku 10 w Sulechowie, w: Obwodnica Sulechowa, woj. lubuskie. Badania archeologiczne na stanowiskach 10, 25, 26, 27, 28, t. 1, red. B. Gruszka, A. Jaszewska i S. Kałagate, Zielona Góra, s. 33-168.

Rzeźnik P. 1997, Wznowienie badań wykopaliskowych na wczesnośredniowiecznym grodzisku w Gostyniu, gm. Gaworzyce, „Śląskie Sprawozdania Archeologiczne”, t. 39, s. 263-286.

Sawicka J. 2016, Paciorek „oliwkowaty” z metalowa tuleja z grodziska w Polupinie, stan. 2. Analiza porównawcza, w: Wczesnośredniowieczny gród w Polupinie, stan. 2. Nowe analizy i interpretacje źródeł archeologicznych i przyrodniczych, red. B. Gruszka, Zielona Góra, s. 109-118.

Siemianowska S. 2010, Typ Bruszczewo i dalkowsko-obrzańska grupa form naczyń wczesnośredniowiecznych. Uwagi w kwestii zasięgu występowania, chronologii oraz genezy, „Śląskie Sprawozdania Archeologiczne", t. 52, s. 203-222.

Stoksik H. 2007, Technologia warsztatu ceramicznego średniowiecznego Śląska w świetle badań specjalistycznych $i$ eksperymentalnych, Wrocław.

Stoksik H. i Paternoga M. 2009, Technologiczno-stylistyczne kategorie ceramiki wczesnośredniowiecznej z pótnocnych rejonów Śląska w świetle badań fizykochemicznych, „Szkło i Ceramika”, R. 60 (3/2009), s. $34-40$.

Wachowski K. 1997, Ślask w dobie przedpiastowskiej. Studium archeologiczne, Wrocław. 